\title{
PEMETAAN PERGERAKAN MASYARAKAT KABUPATEN ROKAN HULU PROVINSI RIAU DENGAN SISTEM INFORMASI GEOGRAFIS (SIG)
}

\author{
Fitra Ramdhani \\ Prodi Teknik Sipil, Fakultas Teknik Universitas Abdurrab \\ J1. Riau Ujung No.73 Pekanbaru, Riau \\ E-Mail : fitra.ramdhani@univrab.ac.id
}

\begin{abstract}
ABSTRAK
Kabupaten Rokan Hulu merupakan sebuah kabupaten hasil pemekaran Kabupaten Kampar yang beribu kota di Pasir Pangaraian, Provinsi Riau. Pembangunan transportasi pada daerah ini harus mampu menunjang upaya pemerataan dan penyebaran pembangunan daerah. Kebutuhan akan pergerakan selalu menimbulkan permasalahan, khususnya pada saat orang ingin bergerak untuk tujuan yang sama di dalam daerah tertentu dan pada saat yang bersamaan pula. Penelitian ini bertujuan untuk mengetahui besarnya estimasi sebaran pergerakan masyarakat di Kabupaten Rokan Hulu dengan memahami pola pergerakan menggunakan metode sintetis (interaksi spasial) yang biasa disebut model gravity (GR) dalam bentuk Matrik Asal Tujuan (MAT) dan garis keinginan (desire line) dengan System Informasi Geografis (SIG). Sebaran pergerakan dilakukan dengan membagi Kabupaten Rokan Hulu menjadi 16 zona. Analisis sebaran pergerakan menggunakan Model Gravity dengan Batasan-Bangkitan-Tarikan (PACGR). Sebaran pergerakan terbesar yang terjadi di Kabupaten Rokan Hulu sebesar $75 \%$ berbasis pergerakan internal dan $25 \%$ berbasis pergerakan antar zona. Sebaran pergerakan antar zona terbesar yang terjadi di Kecamatan Pendalian IV Koto yang mempunyai tujuan pergerakan ke kecamatan Rokan IV Koto. Sebaran pergerakan terbesar yang terjadi untuk Kecamatan Rambah Samo, Kunto Darussalam dan Pagaran Tapah mempunyai tujuan pergerakan ke kecamatan Ujung Batu. Hal ini dikarenakan Kecamatan Ujung Batu merupakan pusat industri dan perdagangan di Kabupaten Rokan Hulu
\end{abstract}

Kata-kata kunci : Sebaran Pergerakan, Model Gravity, Matrik Asal Tujuan (MAT), System Informasi Geografis (SIG)

\section{ABSTRACT}

Rokan Hulu is a regency from region expansion of Kampar Regency with Pasir Pangaraian as a capital of regency, Riau Province. Transportation Development in this area should be able to support distribution and dissemination of regional development. The need for movement always creates of problems, especially when people want to move for same purpose in certain area at the same time. This research aims to determine the magnitude of estimated distribution movement in Rokan Hulu by knowing movement pattern using synthetic method (spatial interaction) called gravity model (GR) in Destination Origin Matrices (MAT) and desire line with Geographic Information Systems (GIS). Movement Distribution is performed with dividing Rokan Hulu into 16 zones. Movement analysis distribution using Gravity Model with trip generation and trip attraction (PACGR).The largest distribution of movement in Rokan Hulu is $75 \%$ based on internal movement and $25 \%$ based on inter-zone movement. The largest Distribution of inter-zone movement that occurred in Pendalian IV Koto District which has purpose of movement to Rokan IV Koto District. The largest distribution of movement occurred for Rambah Samo, Kunto Darussalam and Pagaran Tapah District has purpose of movement to Ujung Batu District. This is because Ujung Batu District is center of industry and commerce in Rokan Hulu.

Key words: Distribution Of Movement, Gravity Models, Destination Origin Matrices (O-D Matrix), Geographic Information Systems (GIS)

\section{PENDAHULUAN}

Rokan Hulu adalah salah satu Kabupaten di Provinsi Riau yang beribu kota di Pasir Pengaraian. Kabupaten Rokan Hulu merupakan sebuah kabupaten hasil pemekaran Kabupaten Kampar, yang berdiri pada tanggal 12 Oktober 1999 berdasarkan UU Nomor 53 tahun 1999 dan UU No 11 tahun 2003 tentang perubahan UU RI No 53 tahun 1999. Pembangunan transportasi harus mampu menunjang upaya pemerataan dan penyebaran pembangunan, pertumbuhan ekonomi serta stabilitas daerah di Kabupaten Rokan Hulu. Hal ini dikarenakan jaringan transportasi yang semakin berkembang luas dan semakin meningkatnya kebutuhan mobilitas manusia dan barang serta tuntutan peningkatan kualitas pelayanan di masa yang akan datang. 


\section{RABIT : Jurnal Teknologi dan Sistem Informasi Univrab}

Volume 4 No. 2 | Juli 2019 : 97-108

Pergerakan merupakan aktivitas yang kita lalukan sehari-hari dengan berbagi macam alasan dan tujuan. Pada prinsipnya seseorang melakukan pergerakan untuk memenuhi kebutuhan hidup yang tidak dapat dipenuhi di tempat tinggalnya. Hal ini menyebabkan terjadinya suatu pergerakan dalam proses pemenuhan kebutuhan tersebut. Jika kebutuhan akan pergerakan yang terjadi besar maka kapasitas jaringan transportasi harus dapat menampung kebutuhan akan pergerakan tersebut.

Kebutuhan akan pergerakan selalu menimbulkan permasalahan, khususnya pada saat orang ingin bergerak untuk tujuan yang sama di dalam daerah tertentu dan pada saat yang bersamaan pula. Kemacetan, keterlambatan, polusi suara dan udara adalah beberapa permasalahan yang timbul akibat adanya pergerakan. Salah satu usaha untuk dapat mengatasinya adalah dengan memahami pola pergerakan yang akan terjadi, misalnya dari mana dan hendak ke mana, besarnya, dan kapan terjadinya. Informasi jarak, waktu, biaya, atau kombinasi ketiganya digunakan sebagai ukuran aksesibilitas (kemudahan). Adapun pengertian dari pola pergerakan dalam sistem transportasi dijelaskan dalam bentuk arus pergerakan (baik kendaraan, penumpang atau barang) yang bergerak dari zona asal ke zona tujuan di dalam daerah tertentu dan selama periode tertentu.

Sebaran pergerakan yang terjadi menghubungkan interaksi antara tata guna lahan, jaringan transportasi dan arus lalu lintas. Sebaran pergerakan merupakan salah satu tahapan dalam Model Perencanaan Transportasi. Pada tahapan ini, jumlah pergerakan yang dibangkitkan dari suatuzona asal atau yang tertarik ke suatu zona tujuan akan disebarkan pada setiap zona asal dan tujuan yang ada. Pola sebaran arus lalu lintas antara zona asal $i$ ke zona tujuan $d$ adalah hasil dari dua hal yang terjadi secara bersamaan. Distribusi perjalanan atau pergerakan tersebut dapat dinyatakan dalam bentuk matriks asal tujuan (MAT) maupun dengan diagram garis keinginan (desire line). Pola pergerakan dapat dihasilkan jika suatu MAT dibebankan ke suatu system jaringan transportasi. MAT dapat memberikan indikasi rinci mengenai kebutuhan akan pergerakan sehingga MAT memegang peran yang sangat penting dalam berbagai kajian perencanaan dan manajemen transportasi, sedangkan garis keinginan membantu dalam memberikan gambaran arah atau orientasi pergerakan tersebut.

Sebaran pergerakan Kota Manado dengan menggunakan Metode sintetis gravity dua batasan menghasilkan distribusi perjalanan terbesar masyarakat di Kota Manado adalah pergerakan menuju ke zona 9 (KecamatanWenang) yaitu sebesar 36,64\% ini dikarenakan Kecamatan Wenang merupakan pusat kegiatan Kota Manado, pergerakan yang terbesar kedua adalah pergerakan menuju ke zona 2 (Kecamatan Malalayang) yaitu sebesar $18,02 \%$, dan pergerakanyang terbesar ketiga adalah pergerakan menuju ke zona 4 (Kecamatan Sario) yaitu sebesar $14,27 \%$ dan bangkitan terbesar berada pada zona 8 (Kecamatan Wanea) yaitu sebesar 11,87\% (Wayongkere,V.dan Ferdinandus, R.R.J., 2012). Dengan metode gravity, dilakukan juga penelitian di Kabupaten Rokan Hulu untuk mengetahui besarnya estimasi sebaran pergerakan yang terjadi dengan menggunakan metode sintetis (interaksi spasial) yang biasa disebut model gravity (GR) dalam bentuk Matrik Asal Tujuan dan garis keinginan (desire line) dalam System Informasi Geografis (SIG).

\section{Daerah kajian}

Daerah kajian adalah suatu daerah georafis yang di dalamnya terletak semua zona asal dan zona tujuan yang diperhitiungkan dalam model kebutuhan akan transportasi. (Tamin, 2014). Gambar 1. melukiskan sistem jaringan jalan suatu daerah kajian yang terdiri dari jalan satu arah masing-masing mencerminkan satu ruas jalan atau pergerakan membelok di persimpangan dan berakhir pada titik ujung masing-masing yang disebut simpul. Sistem jaringan transportasi dicerminkan dalam bentuk ruas dan simpul yang 


\section{RABIT : Jurnal Teknologi dan Sistem Informasi Univrab}

Volume 4 No. 2 | Juli 2019 : 97-108

semuanya dihubungkan ke pusat zona. Hambatan pada setiap ruas jalan dinyatakan dengan jarak, waktu tempuh atau biaya gabungan. Nilai tersebut kemudian dijumlahkan untuk mendapatkan total hambatan untuk setiap zona asal dan tujuan. Semua ini dapat dinyatakan dalam bentuk matrik.

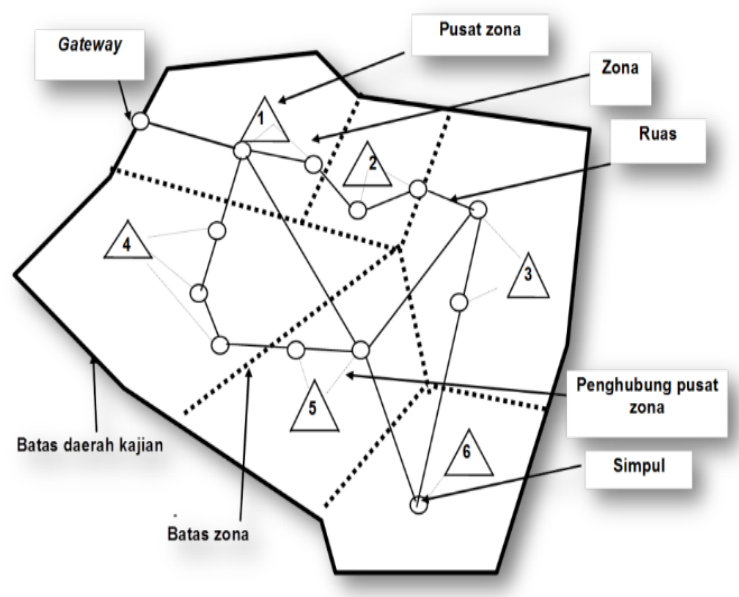

Gambar 1. Daerah kajian sederhana dengan definisinya

Sumber : Tamin, 2014

Zona merupakan sebidang tanah yang mempunyai satu kegiatan saja. Segitiga pada gambar di atas merupakan pusat zona. Pusat zona diasumsikan sebagai tempat dimana pergerakan dimulai dari zona tersebut dan tempat ke mana pergerakan tersebut akan berakhir. Daerah Kajian pada penelitian ini yaitu Kabupaten Rokan Hulu dengan setiap kecamatan diasumsikan sebagai zona.

\section{Sebaran pergerakan}

Sebaran adalah interaksi antara tata guna lahan, jaringan transportasi dan arus lalu lintas. Ketiga aspek inilah yang memengaruhi seseorang dalam melakukan perjalanan dalam rangka memenuhi kebutuhannya. Akibatnya, tercipta pola spasial arus lalu lintas yang merupakan fungsi dari tata guna lahan dan sistem jaringan transportasi. Sedangkan sebaran pergerakan merupakan proses menghitung jumlah pergerakan yang terjadi antara satu zona dengan semua zona lainnya dalam daerah kajian. Bentuk pola sebaran dituangkan dalam Matriks Asal Tujuan (MAT) seperti pada Tabel 1. Model sebaran pergerakan berfungsi untuk memberikan peramalan atas besarnya lalulintas dengan informasi daerah asal dan daerah tujuan dari pergerakan tersebut. Selain itu juga bertujuan untuk mendistribusikan atau mengalokasikan jumlah perjalanan yang berasal dari setiap zona dan diantara seluruhzona tujuan yang memungkinkan.

\section{Matrik asal tujuan (MAT)}

MAT adalah matrik berdimensi dua yang berisi informasi mengenai besarnya pergerakan antarlokasi (zona) dalam daerah tertentu. Baris menyatakan zona asal dan kolom menyatakan zona tujuan, sehingga sel matriksnya menyatakan besarnya arus dari zona asal ke zona tujuan. Jumlah pergerakan yang dibangkitkan dari suatu zona asal $\boldsymbol{i}$ tersebut $\left(\boldsymbol{O}_{\boldsymbol{i}}\right)$ harus sama dengan jumlah pergerakan yang berasal dari zona asal $\boldsymbol{i}$ tersebut yang menuju ke setiap zona tujuan $\boldsymbol{d}(\boldsymbol{D d})$. Sebaliknya, jumlah pergerakan yang tertarik ke suatu zona tujuan $\boldsymbol{d}\left(\boldsymbol{D}_{\boldsymbol{d}}\right)$ harus sama dengan total pergerakan yang menuju ke zona $\boldsymbol{d}$ tersebut yang berasal dari setiap zona asal $\boldsymbol{i}(\boldsymbol{O} \boldsymbol{i})$. Kedua batasan ini ditunjukkan pada persamaan (1) berikut:

$O_{i}=\sum_{d=1}^{N} T_{i d} ; D_{d}=\sum_{i=1}^{N} T_{i d}$

$O_{i} \quad=$ jumlah pergerakan yang berasal dari zona asal $i$

$D_{d} \quad=$ jumlah pergerakan yang menuju ke zona tujuan $d$

$T_{i d} \quad=$ pergerakan dari zona asal $i$ ke zona tujuan d

$T \quad=$ total matriks

$\mathrm{N} \quad=$ jumlah zona

Jika MAT yang dihasilkan memenuhi kedua batasan (1), model tersebut dikenal sebagai model dengan-dua-batasan; jika hanya salah satu dipenuhi, model disebut model dengan-satubatasan (model dengan-batasan-bangkitan atau model denganbatasan- tarikan); jika tidak ada yang dipenuhi, model disebut model tanpabatasan. 
Tabel 1. Bentuk Umum Matrik Asal Tujuan (MAT)

\begin{tabular}{|c|c|c|c|c|c|c|}
\hline Zona & 1 & 2 & 3 & $\ldots$ & $\mathrm{N}$ & $O_{1}$ \\
\hline 1 & $T_{11}$ & $T_{12}$ & $T_{13}$ & $\ldots$ & $T_{1 \mathrm{~N}}$ & $O_{1}$ \\
\hline 2 & $T_{21}$ & $T_{22}$ & $T_{23}$ & $\ldots$ & $T_{2 \mathrm{~N}}$ & $O_{2}$ \\
\hline 3 & $T_{31}$ & $T_{32}$ & $T_{33}$ & $\ldots$ & $T_{3 \mathrm{~N}}$ & $O_{3}$ \\
\hline$\cdot$ & $\cdot$ & $\cdot$ & $\cdot$ & $\ldots$ & $\cdot$ &. \\
$\cdot$ & $\cdot$ & $\cdot$ & $\cdot$ & $\ldots$ &. &. \\
\hline$\cdot$ & $\cdot$ & $\cdot$ & $\cdot$ & $\ldots$ &. &. \\
\hline$D_{d}$ & $T_{\mathrm{N} 1}$ & $T_{\mathrm{N} 2}$ & $T_{\mathrm{N} 3}$ & $\ldots$ & $T_{\mathrm{NN}}$ & $O_{\mathrm{N}}$ \\
\hline \hline
\end{tabular}

Sumber: Tamin (2008)

\section{Model gravity (GR)}

Pada model gravity, penyebaran pergerakan didasarkan pada aksesibilitas, bangkitan dan tarikan dari zona asal ke zona tujuan. Gambaran tingkat kemudahan dalam mencapai zona tujuan dalam model ini dinyatakan dalam fungsi biaya perjalanan atau fungsi hambatan (impedance function). Model ini diilhami oleh konsep hukum Gravity Newton (Tamin, 2000). Terdapat 4 (empat) jenis model GR, yaitu tanpa-batasan (UCGR), dengan-batasan-bangkitan (PCGR), dengan-batasan-tarikan (ACGR), dan denganbatasan-bangkitan-tarikan (PACGR). Model PCGR dan ACGR sering disebut model dengansatu-batasan (SCGR), sedangkan model PACGR disebut model dengan-dua-batasan (DCGR).

\section{Model gravity dengan batasan-bangkitan- tarikan (PACGR)}

Model dengan batasan bangkitan tarikan pergerakan ini mempunyai prinsip bahwa bangkitan dan tarikan pergerakan harus selalu sama dengan yang dihasilkan oleh tahap bangkitan pergerakan. Dengan kata lain, model PACGR menghasilkan MatriksAsal-Tujuan dengan Jumlah Bangkitan danTarikan pergerakan yang sama dengan total pergerakan dari dan ke setiap zona yang diperkirakan oleh tahap bangkitan pergerakan (hasil lapangan). Analisis sebaran pergerakan di Kabupaten Rokan Hulu menggunakan analisis model gravity dengan batasan bangkitan tarikan pergerakan (PACGR) menggunakan rumus umum model gravity seperti pada persamaan (2), dengan menggunakan syarat batas dan factor penyeimbang seperti pada persamaan di bawah ini:

$T_{i d}=A_{i} \cdot O_{i} \cdot B_{d} \cdot D_{d} \cdot f\left(C_{i d}\right)$

Syarat batas

$$
\begin{gathered}
O_{i}=\sum_{d=1}^{N} T_{i d} ; D_{d}=\sum_{i=1}^{N} T_{i d} ; \\
\sum_{i=1}^{N} O_{i}=\sum_{d=1}^{N} D_{d}=\sum_{i=i}^{N} \sum_{d=1}^{N} T_{i d}
\end{gathered}
$$

Faktor penyeimbang

$$
\begin{aligned}
& A_{i}=\frac{1}{\sum_{d=1}^{N} B_{d} \cdot D_{d} \cdot f\left(C_{i d}\right)} \text { for all } \mathrm{i} \\
& B_{d}=\frac{1}{\sum_{i=1}^{N} A_{i} \cdot O_{i} \cdot f\left(C_{i d}\right)} \text { for all } \mathrm{d}
\end{aligned}
$$

$\boldsymbol{T}_{\boldsymbol{i d}}=$ jumlah pergerakan dari zona asal $\boldsymbol{i}$ ke zona tujuan $\boldsymbol{d}$

$\boldsymbol{A}_{\boldsymbol{i}} ; \boldsymbol{B}_{\boldsymbol{d}}=$ faktor penyeimbang masing-masing untuk setiap asal $\boldsymbol{i}$ dan tujuan $\boldsymbol{d}$

$\boldsymbol{O}_{\boldsymbol{i}} \quad=$ total pergerakan dari zona asal $\boldsymbol{i}$

$\boldsymbol{D}_{\boldsymbol{d}} \quad=$ total pergerakan ke zona tujuan $\boldsymbol{d}$

$\boldsymbol{f}\left(\boldsymbol{C}_{i d}\right)=$ fungsi umum jarak perjalanan / fungsi hambatan

Dimana, kedua faktor penyeimbang $A_{i}$ dan $B_{d}$ menjamin bahwa total 'baris' dan 'kolom' dari matriks hasil pemodelan harus sama dengan total 'baris' dan 'kolom' dari matriks hasil bangkitan pergerakan dihitung sesuai dengan persamaan (2). Proses pengulangan $A_{i}$ dan $B_{d}$ dilakukan secara bergantian. Hasil akhir akan selalu sama dari manapun pengulangan dimulai ('baris' atau 'kolom').

\section{Fungsi hambatan}




\section{RABIT : Jurnal Teknologi dan Sistem Informasi Univrab}

Volume 4 No. 2 | Juli 2019 : 97-108

Fungsi hambatan merupakan hal yang terpenting untuk diketahui dengan menganggap $\boldsymbol{f}\left(\boldsymbol{C}_{\text {id }}\right)$ sebagai ukuran aksebilitas (kemudahan) antar zona $i$ dengan zona $d$, dengan persamaan (7). Hambatan dalam transportasi yang berkaitan dengan aksesibilitas (kemudahan) pergerakan dari zona asal ke zona tujuan biasa nya menggunakan nilai jarak, waktu dan biaya. Nilai inilah yang disebut sebagai fungsi hambatan.

\section{$\boldsymbol{f}\left(\boldsymbol{C}_{i d}\right)=\boldsymbol{C}_{\boldsymbol{i d}}{ }^{-\beta \mathrm{Cid}}$ (Fungsi eksponensial-negatif)}

(7)

$\boldsymbol{f}\left(\boldsymbol{C}_{i d}\right)=$ Fungsi eksponensial-negatif

$\boldsymbol{C}_{\boldsymbol{i} \boldsymbol{d}}=$ Jarak, waktu, biaya perjalanan dari zona asal i ke zona tujuan $\mathrm{d}$

$\beta \quad=\mathrm{k} / \boldsymbol{C}_{i d}$ rata-rata $(\mathrm{k}=$ konstanta berkisar 2-3)

\section{METODE}

\section{Teknik pengumpulan data}

Penelitian ini dilakukan pada ruas jalan kolektor di Kabupaten Rokan Hulu. Teknik pengumpulan data terbagi 2 yaitu pengumpulan data primer dan data sekunder. Pengumpulan data primer dilakukan dengan metode survey. Data jumlah bangkitan dan tarikan pergerakan lalu lintas diperoleh dengan melakukan survey volume lalu lintas pada 16 kecamatan yang ada di Kabupaten Rokan Hulu.

Tabel 2. Pembagian zona Kabupaten Rokan Hulu

\begin{tabular}{|c|l|}
\hline Zona & \multicolumn{1}{|c|}{ Kecamatan } \\
\hline 1 & Rokan IV koto \\
\hline 2 & Pendalian IV Koto \\
\hline 3 & Tandun \\
\hline 4 & Kabun \\
\hline 5 & Ujung Batu \\
\hline 6 & Rambah Samo \\
\hline 7 & Rambah \\
\hline 8 & Rambah Hilir \\
\hline 9 & Bangun Purba \\
\hline 10 & Tambusai \\
\hline 11 & Tambusai Utara \\
\hline 12 & Kepenuhan \\
\hline 13 & Kepenuhan Hulu \\
\hline 14 & Kunto Darussalam \\
\hline 15 & Pagaran Tapah Darussalam \\
\hline 16 & Bonai Darussalam \\
\hline
\end{tabular}

Dimana, setiap kecamatan ditentukan sebagai zona. Survey volume lalu lintas dilakukan pada16 zona dengan setiap zona terdiri dari 2 titik survey. Maka, total titik survey sebanyak 32 titik yang tersebar merata di seluruh zona kecamatan seperti yang diilustrasikan pada Gambar 2.

Survey volume lalu lintas dilakukan 2 hari yaitu Hari Rabu dan Hari Minggu dengan mengambil waktu sibuk pagi, siang dan sore. Sedangkan pengumpulan data sekunder dengan mengambil data statistic sosial ekonomi pada Badan Pusat Statistik. Pembagian zona Kabupaten Rokan Hulu dapat dilihat pada Tabel 2.

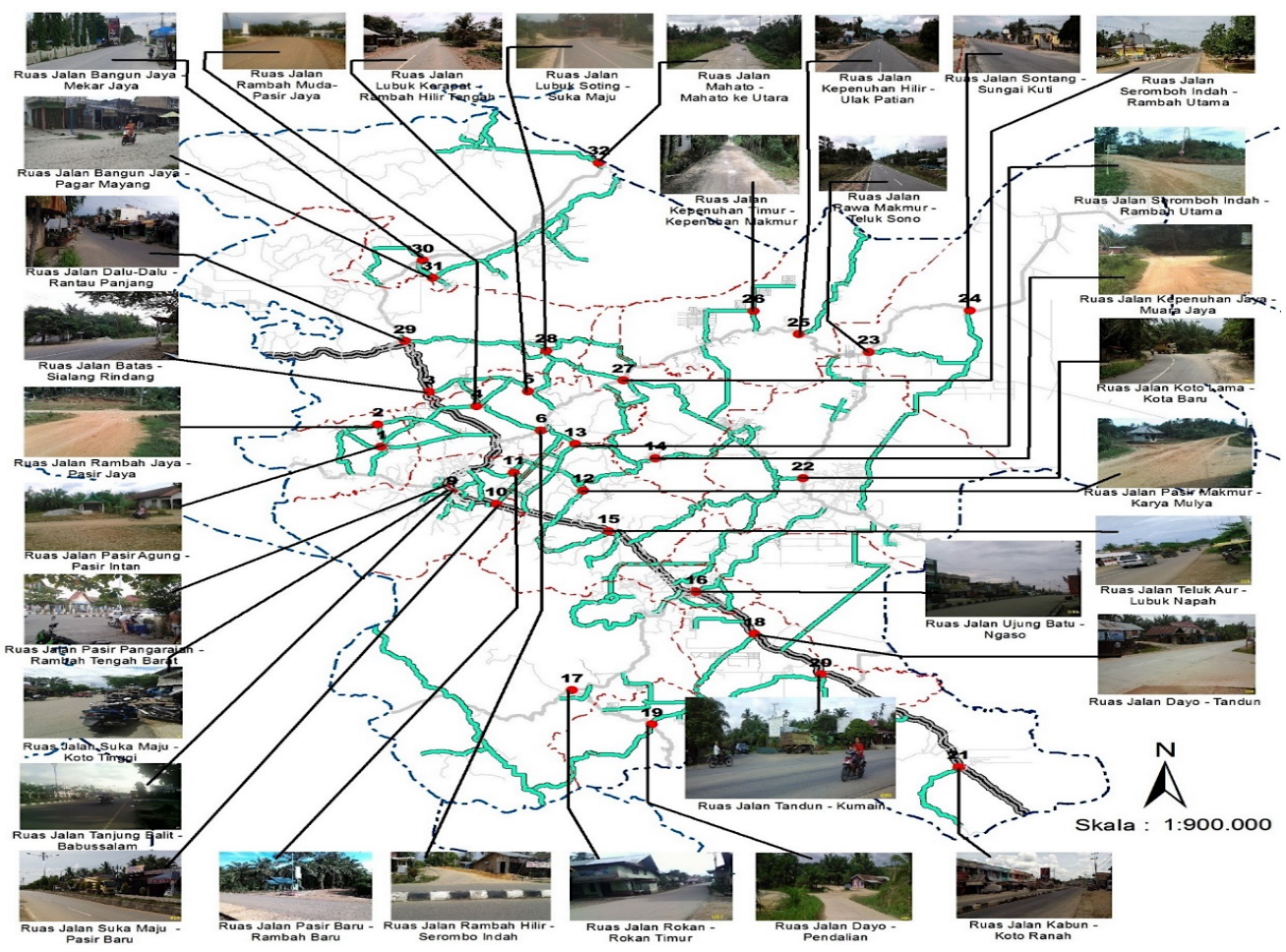


Gambar 2. Lokasi survey volume lalu lintas dengan 32 titik survey pada 16 kecamatan di Kabupaten Rokan Hulu

\section{HASIL}

Berdasarkan hasil survey volume lalu lintas diperoleh jumlah bangkitan dan tarikan pergerakan masing-masing zona perkecamatan di Kabupaten Rokan Hulu. Dari hasil tahap bangkitan pergerakan diperkirakan terjadi bangkitan dan tarikan pergerakan pada setiap zona seperti yang terlihat pada Tabel 3. Pola pergerakan di suatu wilayah disebabkan oleh adanya interaksi arus lalu lintas dalam melalukan aktifitas. Jika suatu wilayah memiliki kepadatan penduduk cukup besar, maka semakin besar pergerakan lalu lintas yang dihasilkan. Untuk mengetahui pola pergerakan dengan menggunakan Model Gravity dua batasan (bangkitan dan tarikan) dibutuhkan informasi data seperti jarak antar zona, waktu tempuh perjalanan, dan biaya perjalanan. Berdasarkan hasil penelitian sebelumnya salah satu faktor yang mempengaruhi bangkitan dan tarikan pergerakan di Kabupaten Rokan Hulu yaitu factor jarak yang diperoleh dari persamaan model bangkitan dan tarikan dengan analisis regresi metode stepwise 2 (Ramdhani dan Trisnawan, 2018). Hal yang sama juga dijelaskan oleh Pramesti, N.D., dkk (2014) bahwa dari analisis regresi linear dapat diketahui variable yang mempengaruhi pola pergerakan, seperti hal nya hasil penelitian di Kota Surakarta pergerakan yang terjadi lebih sensitif terhadap jarak dibandingkan dengan Kota Semarang. Oleh karena itu, penelitian ini menggunakan data aksesibilitas antar zona menggunakan data jarak seperti terlihat pada Tabel 4.

Tabel 3 . Bangkitan dan tarikan pergerakan pada setiap zona

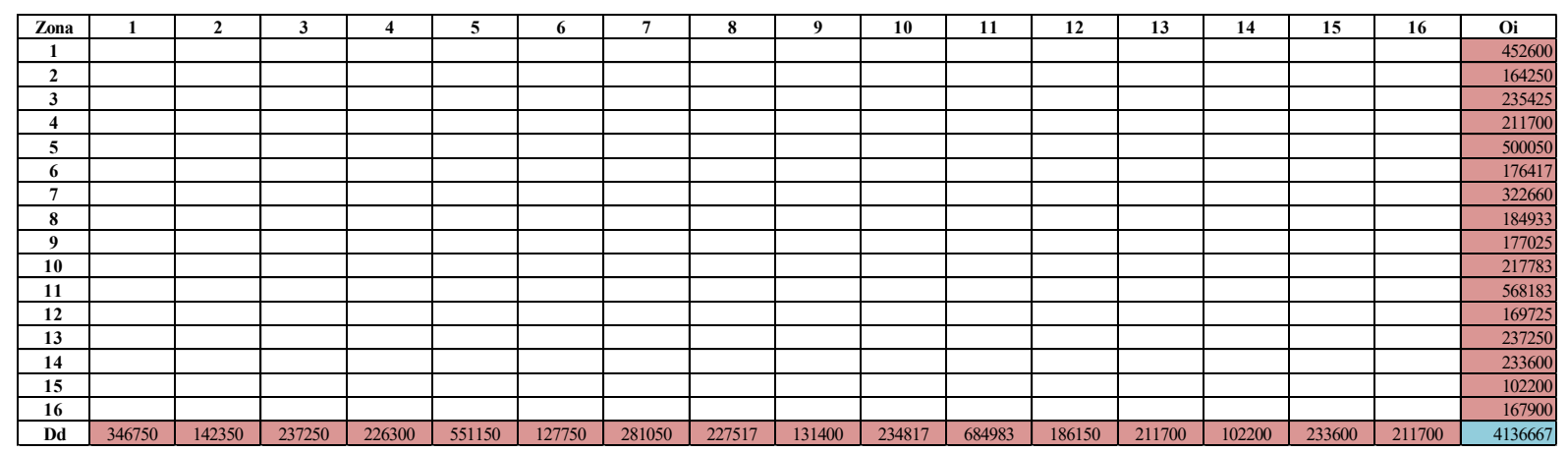

Tabel 4. Matrik jarak $\left(C_{i d}\right)$

\begin{tabular}{|c|c|c|c|c|c|c|c|c|c|c|c|c|c|c|c|c|}
\hline Zona & 1 & 2 & 3 & 4 & 5 & 6 & 7 & 8 & 9 & 10 & 11 & 12 & 13 & 14 & 15 & 16 \\
\hline 1 & 0,00 & 12,00 & 50,00 & 70,00 & 25,00 & 35,00 & 55,00 & 70,00 & 75,00 & 80,00 & 120,00 & 104,00 & 72,00 & 48,00 & 36,00 & 82,00 \\
\hline 2 & 12,00 & 0,00 & 22,00 & 52,00 & 33,00 & 54,00 & 71,00 & 79,00 & 87,00 & 92,00 & 132,00 & 116,00 & 84,00 & 49,00 & 48,00 & 94,00 \\
\hline 3 & 50,00 & 22,00 & 0,00 & 29,00 & 12,00 & 20,00 & 31,00 & 45,00 & 50,00 & 55,00 & 95,00 & 79,00 & 59,00 & 23,00 & 11,00 & 69,00 \\
\hline 4 & 70,00 & 52,00 & 29,00 & 0,00 & 41,00 & 49,00 & 60,00 & 74,00 & 79,00 & 84,00 & 124,00 & 108,00 & 88,00 & 52,00 & 40,00 & 98,00 \\
\hline 5 & 25,00 & 33,00 & 12,00 & 41,00 & 0,00 & 8,00 & 19,00 & 33,00 & 38,00 & 43,00 & 83,00 & 67,00 & 47,00 & 17,00 & 7,00 & 48,00 \\
\hline 6 & 35,00 & 54,00 & 20,00 & 49,00 & 8,00 & 0,00 & 8,00 & 25,00 & 30,00 & 35,00 & 75,00 & 59,00 & 39,00 & 25,00 & 15,00 & 56,00 \\
\hline 7 & 55,00 & 71,00 & 31,00 & 60,00 & 19,00 & 8,00 & 0,00 & 17,00 & 22,00 & 27,00 & 67,00 & 51,00 & 31,00 & 33,00 & 26,00 & 67,00 \\
\hline 8 & 70,00 & 79,00 & 45,00 & 74,00 & 33,00 & 25,00 & 17,00 & 0,00 & 17,00 & 27,00 & 67,00 & 34,00 & 14,00 & 20,00 & 13,00 & 54,00 \\
\hline 9 & 75,00 & 87,00 & 50,00 & 79,00 & 38,00 & 30,00 & 22,00 & 17,00 & 0,00 & 49,00 & 94,00 & 73,00 & 53,00 & 55,00 & 48,00 & 89,00 \\
\hline 10 & 80,00 & 92,00 & 55,00 & 84,00 & 43,00 & 35,00 & 27,00 & 27,00 & 49,00 & 0,00 & 40,00 & 35,00 & 21,00 & 41,00 & 50,00 & 78,00 \\
\hline 11 & 120,00 & 132,00 & 95,00 & 124,00 & 83,00 & 75,00 & 67,00 & 67,00 & 94,00 & 40,00 & 0,00 & 75,00 & 61,00 & 81,00 & 90,00 & 118,00 \\
\hline 12 & 104,00 & 116,00 & 79,00 & 108,00 & 67,00 & 59,00 & 51,00 & 34,00 & 73,00 & 35,00 & 75,00 & 0,00 & 21,00 & 21,00 & 32,00 & 51,00 \\
\hline 13 & 72,00 & 84,00 & 59,00 & 88,00 & 47,00 & 39,00 & 31,00 & 14,00 & 53,00 & 21,00 & 61,00 & 21,00 & 0,00 & 20,00 & 30,00 & 40,00 \\
\hline 14 & 48,00 & 49,00 & 23,00 & 52,00 & 17,00 & 25,00 & 33,00 & 20,00 & 55,00 & 41,00 & 81,00 & 21,00 & 20,00 & 0,00 & 10,00 & 31,00 \\
\hline 15 & 36,00 & 48,00 & 11,00 & 40,00 & 7,00 & 15,00 & 26,00 & 13,00 & 48,00 & 50,00 & 90,00 & 32,00 & 30,00 & 10,00 & 0,00 & 41,00 \\
\hline 16 & 82,00 & 94,00 & 69,00 & 98,00 & 48,00 & 56,00 & 67,00 & 54,00 & 89,00 & 78,00 & 118,00 & 51,00 & 40,00 & 31,00 & 41,00 & 0,00 \\
\hline
\end{tabular}




\section{RABIT : Jurnal Teknologi dan Sistem Informasi Univrab}

Volume 4 No. 2 | Juli 2019 : 97-108

Salah satu fungsi hambatan yang digunakan untuk sebaran pergerakan di Kabupaten Rokan Hulu adalah nilai jarak, dengan menganggap fungsi hambatan mengikuti fungsi eksponensial negatif didapat matrik exp $\left(-\beta C_{i d}\right)$ seperti pada Tabel 5 diperoleh nilai $\mathrm{C}_{\mathrm{id}}$ rata-rata $=48,703$ dengan menganggap nilai $\mathrm{k}=2,5$ maka $\beta=2,5 / \mathrm{C}_{\mathrm{id}}$ rata-rata maka nilai $\beta=0,05133$. Seperti halnya yang telah dilakukan di Provinsi Jawa Barat tahun 2016 juga menganggap fungsi hambatan dengan menggunakan jarak antar zona dan diperoleh hasil data sebaran pergerakan dengan nilai $\mathrm{C}_{\mathrm{id}}$ ratarata $=141,25$, dan didapatkan fungsi aksesibilitas dengan menggunakan fungsi eksponensial negatif dengan mengasumsi nilai $\mathrm{k}=2$ dan nilai $\beta=$ 0,014159 (Aprilliansyah,Tri.dan Herman, 2014).

Selain itu, Ekowicaksono (2016) melakukan estimasi matriks Origin-Destination perkotaan menggunakan model gravity dengan studi kasus Kota Bogor menggunakan fungsi hambatan berupa fungsi eksponensial negatif $\boldsymbol{f}\left(\boldsymbol{C}_{\boldsymbol{i d}}\right)=\boldsymbol{C}_{\boldsymbol{i}}{ }^{-\beta}$ Cid. Dalam fungsi eksponensial negatif tersebut, nilai parameter $\beta$ dikalibrasi menggunakan metode Hyman. Parameter $\beta$ menggambarkan biaya rata-rata perjalanan di daerah kajian, semakin besar nilai $\beta$, maka semakin kecil nilai biaya rata-rata perjalanan. Biaya perjalanan $\left(\boldsymbol{C}_{\boldsymbol{i d}}\right)$ diasumsikan berbanding lurus dengan jarak.

Tabel 5. Matriks exp $\left(-\beta C_{i d}\right)$
Penelitian ini menggunakan data jarak antar kecamatan di Kabupaten Rokan Hulu sebagai komponen biaya untuk menentukan nilai fungsi hambatan dan diasumsikan bahwa jarak antar kecamatan yang sama bernilai 0. Data jarak antar kecamatan ini yang digunakan untuk menentukan nilai fungsi hambatan yang berupa fungsi eksponensial negatif. Data jarak antar kecamatan juga digunakan untuk mengalibrasi nilai parameter $\beta$ yang terdapat dalam fungsi hambatan.

Selanjutnya dilakukan analisa perhitungan dengan menggunakan proses pengulangan dengan nilai awal $A_{i}$. Pengulangan dimulai dengan menganggap nilai awal $\boldsymbol{A}_{1}=\boldsymbol{A}_{2}=\boldsymbol{A}_{3}=\boldsymbol{A}_{4}=\boldsymbol{A}_{5}=\boldsymbol{A}_{6}$ $=A_{7}=A_{8}=A_{9}=A_{10}=A_{11}=A_{12}=A_{13}=A_{14}=A_{15}=$ $\boldsymbol{A}_{16}=1$. Hasil akhir tidak tergantung pada nilai awal. Nilai awal dapat berupa nilai berapa saja asalkan lebih besar dari nol. Perbedaan nilai awal hanya berpengaruh pada jumlah pengulangan untuk mencapai konvergensi. Semakin besar perbedaan antara nilai awal dengan nilai akhir maka semakin banyak jumlah pengulangan yang dibutuhkan untuk mencapai konvergensi. Untuk perhitungan pengulangan dapat dilihat pada Tabel 6-10 .

\begin{tabular}{|c|c|c|c|c|c|c|c|c|c|c|c|c|c|c|c|c|}
\hline & & & & & & & & & & & & & & & & \\
\hline & & & & & & & & & & & & & & & & \\
\hline 1 & 000000 & 40113 & 76798 & 7510 & 77125 & 65862 & 59414 & 027510 & 21283 & 0,016465 & 02113 & 004803 & 24826 & 85102 & 157563 & \\
\hline 2 & 40113 & 00000 & 23262 & 69305 & 83795 & 62543 & 26134 & 32 & 95 & 0,008893 & 141 & 002594 & 13409 & & 085102 & \\
\hline 3 & 076798 & 323262 & 1,000000 & 225686 & 0,540113 & 0,358213 & 0,203666 & 0,099270 & 0,076798 & 0,059414 & \begin{tabular}{|l}
0,007624 \\
\end{tabular} & $\mid 0,017332$ & 048386 & 307088 & 568562 & 28959 \\
\hline 4 & 027510 & 069305 & 0,225686 & 1,000000 & 0,121896 & 0,080844 & 0,045965 & 0,022404 & 0,017332 & 0,013409 & 0,001721 & 0,003912 & 0,010920 & 0,069305 & 0,128316 & 006536 \\
\hline 5 & 277125 & 83795 & 401 & & 00000 & 663218 & 377080 & 0,183795 & 90 & 0,110003 & 0,014115 & 0,032090 & 0,089584 & 850 & 0,698151 & \\
\hline 6 & 165862 & 062543 & 0,358213 & 80844 & 0,663218 & 1,000000 & 0,663218 & 0,277125 & 0,214 & 0,165862 & 0,021283 & 0,048386 & 0,135075 & 277125 & 0,463026 & 56441 \\
\hline 7 & 0,059414 & 0,026134 & 0,203666 & 0,045965 & 0,377080 & 0,663218 & 1,000000 & 0,417850 & 0,323262 & 0,250087 & 0,032090 & 0,072956 & 0,203666 & 0,183795 & 0,263259 & 0,032090 \\
\hline 8 & 0,027510 & 017332 & 0,099270 & 0,022404 & 0,183795 & 0,277125 & 0,417850 & 1,000000 & 0,4178 & 0,250087 & 0,032090 & 0,174598 & 0,487415 & 0,358213 & 0,513088 & 66254. \\
\hline 9 & 0,021283 & 0,011495 & 0,076798 & 0,017332 & 0,142190 & 0,214393 & 0,323262 & 0,417850 & 1,000000 & 0,080844 & 0,008025 & 0,023584 & 0,065838 & 0,059414 & 0,085102 & 10374 \\
\hline 10 & 0,016465 & 0,008893 & 0,059414 & 0,013409 & 0,110003 & 0,165862 & 0,250087 & 0,250087 & 0,080844 & 1,000000 & 0,128316 & 0,165862 & 0,340289 & 0,121896 & 0,076798 & 018245 \\
\hline 11 & 0,002113 & 0,001141 & 0,007624 & 0,001721 & 0,014115 & 0,021283 & 0,032090 & 0,032090 & 0,008025 & 0,128316 & 1,000000 & 0,021283 & 0,043665 & 0,015641 & 0,009855 &, 002341 \\
\hline 12 & 0,004803 & 0,002594 & 0,017332 & 0,003912 & 0,032090 & 0,048386 & 0,072956 & 0,174598 & 0,023584 & 0,165862 & 0,021283 & 1,000000 & 0,340289 & 0,340289 & 0,193475 & 0,072956 \\
\hline 13 & 024826 & 0,013409 & 0,048386 & 0,010920 & 0,089584 & 0,135075 & 0,203666 & 0,487415 & 0,065838 & 0,340289 & 0,043665 & 0,340289 & 1,000000 & 0,358213 & 0,214393 & 128316 \\
\hline 14 & 0,085102 & 0,080844 & 0,307088 & 0,069305 & 0,417850 & 0,277125 & 0,183795 & 0,358213 & 0,059414 & 0,121896 & 0,015641 & 0,340289 & 0,358213 & 1,000000 & 0,598509 & 0,203666 \\
\hline 15 & 0,157563 & 0,085102 & 0,568562 & 0,128316 & 0,698151 & 0,463026 & 0,263259 & 0,513088 & 0,085102 & 0,076798 & 0,009855 & 0,193475 & 0,214393 & 0,598509 & 1,000000 & 0,121896 \\
\hline 16 & 0,014859 & 0,008025 & 0,028959 & 0,006536 & 0,085102 & 0,056441 & 0,032090 & 0,062543 & 0,010374 & 0,018245 & $\mid 0,002341$ & 0,072956 & 0,128316 & 0,203666 & 0,121896 & $1,00000 \mathrm{C}$ \\
\hline
\end{tabular}


Tabel 6. Perhitungan nilai $\mathrm{B}_{\mathrm{d}}$ (Pengulangan 1)

\begin{tabular}{|c|c|c|c|c|c|c|c|c|c|c|c|c|c|c|c|c|}
\hline Zona $d$ & 1 & 2 & 3 & 4 & 5 & 6 & 7 & 8 & 9 & 10 & 11 & 12 & 13 & 14 & 15 & 16 \\
\hline $\mathrm{A}_{1} \cdot \mathrm{O}_{1} \cdot \exp \left(-\beta \mathrm{B}_{\mathrm{Id} d}\right)$ & 2600,0000 & 244455,1441 & 34758,9924 & 12451,1146 & 125426,9507 & 75069,1313 & 26890,7207 & 12451,1146 & 9632,5993 & 7452,1014 & 956,2267 & 2173,9423 & 11236,2744 & 38517,0550 & 71312,9566 & 6725,0089 \\
\hline $0_{2} \exp \left(-\mathrm{BC}_{\mathrm{Z}_{2}}\right)$ & 13,5604 & 250,0000 & 53095,8448 & 11383,4030 & 30188,2622 & 10272,7381 & 4292,4586 & 2846,8365 & 1888,0737 & 1460,6771 & 187,4288 & 426,1117 & 2202,4081 & 13278,5592 & 13977,9635 & 1318,1606 \\
\hline $\left.\mathrm{BC}_{3 \mathrm{~d}}\right)$ & & & 235 & & & & & 23370 & & & 269 & 57 & & & & \\
\hline $\mathrm{O}_{4} \cdot \exp \left(-\beta \mathrm{C}_{4 \mathrm{~d}}\right)$ & & 677,9417 & 47777,7158 & 00 & 25805 & 74 & 9730,6 & 4742,8 & 3669,2560 & & & 828, & & & & 046 \\
\hline 0,0 & 6576,5504 & 91906,4871 & 270083,5060 & 60954,0529 & 500050,0000 & 331642,2495 & 188559,0714 & 91906,4 & 71101,9366 & 55006,8395 & 7058,2786 & 16046,7082 & 44796,5845 & 208945,6459 & 349110,4105 & 42555,1333 \\
\hline $\left.0_{6} \cdot \mathrm{ex}\right]$ & 60,8173 & 11033,6817 & 63194,7010 & 262,1562 & 117002,7401 & 176416,6667 & 117002,7401 & 48889,5372 & 37822,5834 & 29260,8173 & 3754,6422 & 8536,0257 & 23829,4853 & 48889,5372 & 81685,5807 & 9957,1387 \\
\hline 0 & & & 65 & & 12 & 213993 & $322660, \mathrm{C}$ & & 104303,8 & 80692,9419 & 263 & 23539,9107 & & & 763 & 10354,2263 \\
\hline & & & 18358,3043 & & 33989,7471 & 51249,7218 & 77274,3021 & 184933 & 77274, & 46249,3483 & 5934,5490 & 32289,0290 & 90139,2487 & ;4797 & 94887,0361 & 11566,3422 \\
\hline $.0 . \exp$ & 7,5892 & 2034,9239 & 13595,2511 & 3068,2572 & 25171,1235 & 37953,0061 & 57225,5216 & 73969,8089 & 177025,0000 & 14311,3360 & 1420,6842 & 4174,9323 & 11654,8957 & 10517,7416 & 15065,1384 & 1836,3789 \\
\hline${ }_{10} \cdot 0_{10} \cdot \mathrm{e}$ & .8230 & 6,7496 & 12939,3522 & 0,2300 & 23956,7500 & 36121,9744 & 54464,6931 & 54464,6931 & 17606,3859 & 217783,3333 & 27945,1692 & 36121,9744 & 74109,3058 & 26546,8989 & 16725,4291 & 3973,5139 \\
\hline & & & & & & 12092,5373 & 18233,1210 & 18233,1210 & 4559,8592 & 72907,2292 & 568183,3333 & 12092,5373 & & & 5599,1644 & 1330,2115 \\
\hline & 5,2284 & 0,3154 & 417311 & 3,0074 & 5446,5104 & 8212,2454 & 12382,4191 & 29633,6812 & 4002,7702 & 28150,9242 & 3612,2247 & 169725,0000 & 57755,5763 & 57755,5763 & 32837,6069 & 12382,4191 \\
\hline${ }_{13} .0_{13} \cdot 6$ & 99,9825 & 3181,2561 & 11479,4828 & 2590,7580 & 21253,8540 & 32046,5492 & 48319,7692 & 115639,1677 & 15619,9633 & 80733,6012 & 10359,4436 & 80733,6012 & 237250,0000 & 84985,9773 & 50864,8536 & 30443,0615 \\
\hline & & & & & & & & & & 28474 & & 491,5458 & & & & 47576,3881 \\
\hline & & 7,3995 & 58107,0027 & & 7135 & 3019 & 2690 & & 8697,3995 & 7848,8047 & & 1827 & 138 & & 102200 & 12457,7626 \\
\hline .016 & 1,7614 & 1347,4530 & 4862,2504 & 1097,3416 & 14288,5849 & 9476,4492 & 5387,9458 & 10501,0212 & 1741,7201 & 3063,3795 & 393,0818 & 12249,2748 & 21544,3204 & 34195,5290 & 20466,3243 & 167900,0000 \\
\hline & & & & & & & & & & & & & & & & \\
\hline $\mathrm{Bd}=1$ & & 0,00000154 & 0,00000103 & 0,00000236 & 0,00000074 & 0,00000083 & 0,0000009 & 0,0000010 & 0,0000 & 0,0000014 & & 0,0000019 & & 0,000000 & & 0 \\
\hline
\end{tabular}

Tabel 7. Perhitungan nilai $A_{i}$ (Pengulangan 2)

\begin{tabular}{|c|c|c|c|c|c|c|c|c|c|c|c|c|c|c|c|c|c|c|}
\hline Zona $i$ & $\begin{array}{c}\mathbf{B}_{1}, \mathbf{D}_{1} \cdot \\
\exp \left(-\beta \mathrm{Ci}_{1}\right)\end{array}$ & $\begin{array}{c}\mathrm{B}_{2} \cdot \mathrm{D}_{2} \cdot \\
\exp \left(-\mathrm{BC}_{2}\right)\end{array}$ & $\begin{array}{c}\mathrm{B}_{3}, \mathrm{D}_{3} . \\
\exp \left(-\mathrm{-C}_{3}\right)\end{array}$ & 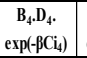 & $\begin{array}{c}\mathrm{B}_{5} \cdot \mathrm{D}_{5 .} \\
\exp \left(-\mathrm{BC}_{5}\right)\end{array}$ & $\begin{array}{c}\mathrm{B}_{6} \cdot \mathrm{D}_{6 \cdot} \\
\exp \left(-\mathrm{BC}_{6}\right)\end{array}$ & $\begin{array}{c}\mathbf{B}_{7} \cdot \mathbf{D}_{7 .} \\
\exp \left(-\mathrm{BC}_{\left.\mathrm{C}_{7}\right)}\right)\end{array}$ & $\begin{array}{c}\mathbf{B}_{8} \cdot \mathrm{D}_{8 \cdot} \\
\exp \left(-\mathrm{BC}_{8}\right)\end{array}$ & $\begin{array}{c}\mathrm{B}_{9} . \mathrm{D}_{9 .} \\
\exp \left(-\mathrm{BC}_{\left.\mathrm{i}_{9}\right)}\right.\end{array}$ & $\begin{array}{c}\mathrm{B}_{10} \cdot \mathrm{D}_{10} \cdot \\
\exp \left(-\beta \mathrm{C}_{10}\right)\end{array}$ & $\begin{array}{c}\mathrm{B}_{11} \cdot \mathbf{D}_{11} \\
\exp \left(-\mathrm{BC}_{11}\right)\end{array}$ & $\begin{array}{c}\mathbf{B}_{12} \cdot \mathrm{D}_{12} \\
\exp \left(-\mathrm{BC}_{12}\right)\end{array}$ & $\begin{array}{c}\mathrm{B}_{13} \cdot \mathrm{D}_{13 \cdot} \\
\exp \left(-\mathrm{BG}_{\left.\mathrm{B}_{13}\right)}\right)\end{array}$ & $\begin{array}{c}\mathrm{B}_{14} \cdot \mathrm{D}_{14} \\
\exp \left(-\mathrm{\beta C} \mathrm{i}_{14}\right)\end{array}$ & $\begin{array}{c}\mathrm{B}_{15} 5 \mathrm{D}_{15} \cdot \\
\exp \left(-\beta \mathrm{Ci}_{15}\right)\end{array}$ & $\begin{array}{c}\mathrm{B}_{16} 6 . \mathrm{D}_{16} \\
\exp \left(-\beta \mathrm{Ci}_{16}\right)\end{array}$ & Total & $\mathrm{Ai}=1 /$ TOTAL $]$ \\
\hline 1 & 0,4275 & 0,1181 & $\begin{array}{l}0,0188 \\
\end{array}$ & $\begin{array}{l}0,0147 \\
0\end{array}$ & 0,1133 & $\begin{array}{l}0,0175 \\
\end{array}$ & $\begin{array}{l}0,0157 \\
\end{array}$ & $\begin{array}{l}0,0066 \\
\end{array}$ & 0,0049 & \begin{tabular}{|l|}
0,0056 \\
\end{tabular} & $\begin{array}{l}0,0022 \\
\end{array}$ & $\begin{array}{l}0,0018 \\
\end{array}$ & \begin{tabular}{|l|l|}
0,0067 \\
\end{tabular} & 0,0084 & $\begin{array}{l}0,0297 \\
\end{array}$ & \begin{tabular}{|l|}
0,0085 \\
\end{tabular} & 0,8001 & 1,24978707 \\
\hline 2 & 0,2309 & 0,2186 & 0,0792 & 0,0370 & 0,0751 & 0,0066 & 0,0069 & 0,0042 & 0,0027 & 0,0030 & 0,0012 & 0,0010 & 0,0036 & 0,0079 & 0,0160 & 0,0046 & 0,6986 & 43134215 \\
\hline 3 & 0,0328 & 0,0707 & 0,2450 & 0,1206 & 0,2208 & 0,0379 & 0,0540 & 0,0240 & 0,0178 & 0,0202 & 0,0081 & 0,0064 & 0,0131 & 0,0302 & 0,1071 & 0,0166 & 1,0251 & 0,97547394 \\
\hline 4 & 0,0118 & 0,0151 & 0,0553 & 0,5344 & 0,0498 & 0,0085 & 0,0122 & 0,0054 & 0,0040 & 0,0046 & 0,0018 & 0,0014 & 0,0029 & 0,0068 & 0,0242 & 0,0038 & 0,7421 & 1,34756587 \\
\hline 5 & 0,1185 & 0,0402 & 0,1323 & 0,0651 & 0,4087 & 0,0701 & 0,1000 & 0,0444 & 0,0330 & 0,0374 & 0,0149 & 0,0119 & 0,0242 & 0,0411 & 0,1315 & 0,0489 & 1,3221 & 0,75634826 \\
\hline 6 & 0,0709 & 0,0137 & 0,0878 & 0,0432 & 0,2711 & 0,1057 & 0,1758 & 0,0669 & 0,0497 & 0,0564 & 0,0225 & 0,0179 & 0,0365 & 0,0272 & 0,0872 & 0,0324 & 1,1650 & 0,85838352 \\
\hline 7 & 0,0254 & 0,0057 & 0,0499 & \begin{tabular}{l|l|}
0,0246 \\
\end{tabular} & 0,1541 & 0,0701 & 0,2651 & 0,1009 & 0,0749 & 0,0851 & 0,0340 & 0,0270 & 0,0550 & 0,0181 & 0,0496 & 0,0184 & 1,0579 & 0,94530835 \\
\hline 8 & 0,0118 & 0,0038 & 0,0243 & 0,0120 & 0,0751 & 0,0293 & 0,1108 & 0,2414 & 0,0969 & 0,0851 & 0,0340 & 0,0647 & 0,1316 & 0,0352 & 0,0966 & 0,0359 & 1,0884 & 0,91881697 \\
\hline 9 & 0,0091 & 0,0025 & 0,0188 & 0,0093 & 0,0581 & 0,0227 & 0,0857 & 0,1009 & 0,2318 & 0,0275 & 0,0085 & 0,0087 & 0,0178 & 0,0058 & 0,0160 & 0,0060 & 0,6292 & 1,58942598 \\
\hline 10 & 0,0070 & 0,0019 & 0,0146 & 0,0072 & 0,0450 & 0,0175 & 0,0663 & 0,0604 & 0,0187 & 0,3402 & 0,1359 & 0,0615 & 0,0918 & 0,0120 & 0,0145 & 0,0105 & 0,9049 & 1,10508499 \\
\hline 11 & 0,0009 & 0,0002 & 0,0019 & 0,0009 & 0,0058 & 0,0023 & 0,0085 & 0,0077 & 0,0019 & 0,0437 & 1,0587 & 0,0079 & 0,0118 & 0,0015 & 0,0019 & 0,0013 & 1,1569 & 0,86439487 \\
\hline 12 & 0,0021 & 0,0006 & 0,0042 & 0,0021 & 0,0131 & 0,0051 & 0,0193 & 0,0421 & 0,0055 & 0,0564 & 0,0225 & 0,3706 & 0,0918 & 0,0334 & 0,0364 & 0,0419 & 0,7473 & 1,33807459 \\
\hline 13 & 0,0106 & 0,0029 & 0,0119 & 0,0058 & 0,0366 & 0,0143 & 0,0540 & 0,1177 & 0,0153 & 0,1158 & 0,0462 & 0,1261 & 0,2699 & 0,0352 & 0,0404 & 0,0737 & $\begin{array}{ll}0,9763 \\
\end{array}$ & 1,02422647 \\
\hline 14 & 0,0364 & 0,0177 & 0,0752 & 0,0370 & 0,1708 & \begin{tabular}{|l|l|l}
0,0293 \\
\end{tabular} & 0,0487 & \begin{tabular}{l|l|}
0,0865 \\
\end{tabular} & 0,0138 & 0,0415 & 0,0166 & 0,1261 & 0,0967 & 0,0983 & 0,1127 & 0,1170 & 1,1242 & 0,88952952 \\
\hline 15 & 0,0674 & 0,0186 & 0,1393 & 0,0686 & 0,2854 & 0,0490 & \begin{tabular}{ll|l}
0,0698 \\
\end{tabular} & 0,1239 & 0,0197 & 0,0261 & 0,0104 & 0,0717 & 0,0579 & 0,0588 & 0,1883 & 0,0700 & 1,3248 & 0,75482587 \\
\hline 16 & 0,0064 & 0,0018 & 0,0071 & 0,0035 & 0,0348 & 0,0060 & 0,0085 & 0,0151 & 0,0024 & 0,0062 & 0,0025 & 0,0270 & 0,0346 & 0,0200 & 0,0230 & 0,5744 & 0,7732 & 1,29339778 \\
\hline
\end{tabular}

Tabel 8. Perhitungan nilai $B_{d}$ (Pengulangan 2)

\begin{tabular}{|c|c|c|c|c|c|c|c|c|c|c|c|c|c|c|c|c|}
\hline Zona $d$. & 1 & 2 & 3 & 4 & 5 & 6 & 7 & 8 & 9 & 10 & 11 & 12 & 13 & 14 & 15 & 16 \\
\hline$\overline{A_{1} \cdot O_{1} \cdot \exp \left(-\beta C_{1 d}\right)}$ & 565653,6292 & 305516,8790 & 434441,3394 & 15561,2421 & 156756,9816 & 93820,4298 & 33607,6751 & 15561,2421 & 12038,6980 & 9313,5400 & $\begin{array}{ll}1195,0798 \\
\end{array}$ & 2716,9650 & 14042,9505 & 48138,1174 & 89126,0113 & 8404,829147 \\
\hline $\mathrm{A}_{2} \cdot \mathrm{O}_{2} \cdot \exp \left(-\beta \mathrm{C}_{2 \mathrm{dd}}\right)$ & 126979,4580 & \begin{tabular}{|l|l|l}
235097,9478 \\
\end{tabular} & 75998,3205 & 16293,5445 & 43209,7321 & 14703,8031 & 6143,9769 & 4074,7971 & 2702,4795 & 2090,7287 & \begin{tabular}{|l|l|l}
268,2747 \\
\end{tabular} & 609,9117 & 3152,3995 & 19006,1615 & 20007,2483 & 1886,738801 \\
\hline $\mathrm{A}_{3} \cdot \mathrm{O}_{3} \cdot \exp \left(-\beta \mathrm{C}_{3 \mathrm{~d}}\right)$ & 17636,8442 & $\begin{array}{l}74237,5116 \\
\end{array}$ & 229650,9515 & 51828,9934 & 124037,4645 & 82263,9011 & 46772,1010 & 22797,4155 & 17636,8442 & 13644,4534 & 1750,8069 & 3980,3880 & 11111,7984 & 70522,9480 & $\begin{array}{ll}130570,7286 \\
\end{array}$ & 6650,508874 \\
\hline $\mathrm{A}_{4} \cdot \mathrm{O}_{4}, \exp \left(-\beta \mathrm{C}_{4 \mathrm{~d}}\right)$ & 7848,1002 & \begin{tabular}{|l|l}
19771,4078 \\
\end{tabular} & $\begin{array}{l}64383,6190 \\
\end{array}$ & 285279,6941 & \begin{tabular}{|l}
34774,4297 \\
\end{tabular} & 23063,0339 & 112,7571 & 6391,3522 & 4944,5641 & 3825,2804 & 490,8461 & 1115,9187 & 3115,2398 & 19771,4078 & 36606,0580 & 1864,49 \\
\hline$A_{5}, 0_{5}, \exp \left(-\beta C_{5 d}\right)$ & 378211,9483 & 204277,1903 & 29046,1031 & 10404,6847 & 104812,1330 & 62730,9819 & 22471,0381 & 10404,6847 & 8049,4126 & 6227,2952 & 799,0640 & $\begin{array}{ll}1816,63933 \\
\end{array}$ & 9389,5122 & 32186,5011 & 59592,1614 & 5619,705492 \\
\hline$A_{6} \cdot 0_{6} \cdot \exp \left(-\beta C_{6 d)}\right)$ & 25117,0035 & 9471,1306 & 54245,2902 & 12242,3999 & $\begin{array}{l}100433,2245 \\
\end{array}$ & 151433,1602 & 100433,2245 & 41965,9733 & 32466,2825 & 25117,0035 & 3222,9230 & 7327,1838 & 20454,8376 & 41965,9733 & 70117,5567 & 8547,043811 \\
\hline$A_{7}, 0_{7} \cdot \exp \left(-\beta C_{7 d}\right)$ & 18122,0162 & 7971,1202 & 62120,8304 & \begin{tabular}{|l|l|}
14019,7987 \\
\end{tabular} & $\begin{array}{l}15014,5068 \\
\end{array}$ & 202290,2929 & $\begin{array}{l}05013,1915 \\
\end{array}$ & 127449,6116 & \begin{tabular}{|l}
98599,2881 \\
\end{tabular} & 76279,7116 & 9787,9366 & 22252,4741 & 62120,8304 & 56059,7760 & 80297,4936 & 9787,936552 \\
\hline $\mathrm{A}_{8} \cdot \mathrm{O}_{8} \cdot \exp \left(-\beta \mathrm{B}_{8 \mathrm{~d}}\right)$ & 4674,5293 & 2945,1089 & 16867,9216 & \begin{tabular}{|l|l|}
3806,8529 \\
\end{tabular} & 31230,3566 & 47089,1143 & 71000,9404 & 169919,8857 & 71000,9404 & 42494,6862 & 5452,7644 & 29667,7079 & 82821,4717 & 60867,4712 & 87183,8194 & 10627,35154 \\
\hline $\mathrm{A}_{9}, \mathbf{O}_{9}, \exp \left(-\beta \mathrm{C}_{9_{\mathrm{d}}}\right)$ & 88,3042 & 3234,3610 & 21608,6453 & 4876,7677 & 40007,6377 & 60323,4940 & 90955,7308 & 117569,5361 & 281368,1343 & 22746,8093 & 2258,0724 & $\begin{array}{l}6635,7459 \\
\end{array}$ & 18524,5940 & 16717,1717 & 23944,9224 & 2918,788258 \\
\hline$A_{10} \cdot 0_{10} \cdot \exp \left(-\beta C_{10 d}\right)$ & 62,6391 & 2140,2729 & 14299,0838 & 3227,1023 & 26474,2448 & 39917,8516 & 60188,1146 & 60188,1146 & 19456,5527 & 240669,0919 & \begin{tabular}{|l|l|}
30881,7869 \\
\end{tabular} & 39917,8516 & 81897,0811 & 29336,5794 & 18483,0206 & 4391,070608 \\
\hline$A_{11} \cdot 0_{11} \cdot \exp \left(-\beta C_{11 d}\right)$ & 1037,6407 & $\begin{array}{l}560,4432 \\
\end{array}$ & 3744,3002 & 845,0360 & 6932,4386 & 10452,7271 & 15760,6161 & 15760,6161 & 3941,5189 & $\begin{array}{ll}63020,6346 \\
\end{array}$ & 491134,7560 & 10452,7271 & 21445,2383 & 7681,9580 & 4839,8890 & 1149,827982 \\
\hline $\mathrm{A}_{12} \cdot \mathrm{O}_{12} \cdot \exp \left(-\mathrm{BC}_{12 \mathrm{~d}}\right.$ & 1090,8364 & 589,1749 & 3936,2556 & 888,3576 & 7287,8372 & 10988,5969 & 16568,6003 & 39652,0759 & 5356,0051 & 37668,0364 & \begin{tabular}{|l|l|}
4833,4261 \\
\end{tabular} & 227104,7097 & 77281,2690 & 77281,2690 & 43939,1674 & 16568,60034 \\
\hline$A_{13} \cdot 0_{13} \cdot \exp \left(-B_{13 d}\right.$ & 6032,6760 & 3258,3268 & 11757,5902 & 2653,5229 & 21768,7599 & 32822,9242 & 49490,3869 & 118440,6971 & 15998,3799 & 82689,4918 & 10610,4164 & \begin{tabular}{|l|l|l|}
82689,4918 \\
\end{tabular} & 242997,7312 & 87044,8879 & 52097,1297 & 31180,58952 \\
\hline $\mathrm{A}_{14} \cdot \mathrm{O}_{14} \cdot \exp \left(-\mathrm{BC}_{14 \mathrm{~d}}\right)$ & 83,6426 & 16798,8202 & 810,9798 & 14401,2417 & 826,6606 & 57585,0195 & 191,4317 & 74434,4966 & 12345,8528 & 25329,2517 & 3250,1579 & 70710,0767 & $\begin{array}{l}74434,4966 \\
\end{array}$ & \begin{tabular}{|l|l|l|l}
207794,0961 \\
\end{tabular} & $\begin{array}{l}124366,5909 \\
\end{array}$ & 42320,60174 \\
\hline$A_{15} \cdot 0_{15} \cdot \exp \left(-\beta C_{15 d}\right)$ & 12154,9048 & 6565,0221 & \begin{tabular}{|l|l|}
43860,6687 \\
\end{tabular} & 9898,7367 & \begin{tabular}{|l|l|}
53857,6051 \\
\end{tabular} & 35719,3427 & 20308,6492 & 39581,2362 & 6565,0221 & 5924,4808 & 760,2079 & 14925,3097 & 16539,0000 & $\begin{array}{l}46170,8846 \\
\end{array}$ & 77143,2035 & 9403,44147 \\
\hline$A_{16} \cdot O_{16} \cdot \exp \left(-\beta C_{160}\right)$ & 3226,7188 & 1742,7928 & 6288,8239 & 1419,2992 & 18480,8240 & 12256,8184 & 6968,7571 & 13581,9975 & 2252,7370 & 3962,1682 & 508,4111 & \begin{tabular}{|l|l|}
15843,1848 \\
\end{tabular} & 27865,3761 & 44228,4211 & 26471,0984 & $\begin{array}{l}217161,4867 \\
\end{array}$ \\
\hline & 15342,8910 & $\begin{array}{l}894177,5099 \\
\end{array}$ & & & 971904,8367 & & & & 594722,7123 & & & 537766,2859 & & & 944786,0994 & \\
\hline $\mathrm{Bd}=1 /$ TOTAL $]$ & 0,00000084 & 0,00000112 & 0,00000134 & 0,00000223 & $\begin{array}{l}0,00000103 \\
\end{array}$ & 0,00000107 & 0,00000111 & 0,00000114 & 0,00000168 & 0,00000151 & 0,00000176 & 0,00000186 & 0,00000130 & 0,00000116 & 0,00000106 & 0,00000264 \\
\hline
\end{tabular}

Tabel 9. Perhitungan nilai $A_{i}$ (Pengulangan 3)

\begin{tabular}{|c|c|c|c|c|c|c|c|c|c|c|c|c|c|c|c|c|c|c|}
\hline Zona $i$ & $\begin{array}{c}\mathrm{B}_{1} \cdot \mathrm{D}_{1} \cdot \\
\exp \left(-\mathrm{BC}_{1}\right)\end{array}$ & $\begin{array}{c}\mathrm{B}_{2} \cdot \mathrm{D}_{2} \cdot \\
\exp \left(-\mathrm{BC}_{2}\right)\end{array}$ & $\begin{array}{c}\mathrm{B}_{3} \cdot \mathrm{D}_{3} \cdot \\
\exp \left(-\mathrm{BC}_{3}\right)\end{array}$ & $\begin{array}{c}\mathrm{B}_{4} \cdot \mathrm{D}_{4} \\
\exp \left(-\mathrm{BC}_{4}\right)\end{array}$ & $\begin{array}{c}\mathrm{B}_{5}, \mathrm{D}_{5} . \\
\exp \left(-\mathrm{BCi}_{5}\right)\end{array}$ & $\begin{array}{c}\mathrm{B}_{6} \cdot \mathrm{D}_{6 \cdot} \\
\exp \left(-\mathrm{BC}_{6}\right)\end{array}$ & $\begin{array}{c}\mathrm{B}_{7} \cdot \mathrm{D}_{7} \cdot \\
\exp \left(-\mathrm{BC}_{7}\right)\end{array}$ & $\begin{array}{c}\mathbf{B}_{8} \cdot \mathrm{D}_{8 \cdot} \\
\exp \left(-\mathrm{BC}_{8}\right)\end{array}$ & $\begin{array}{c}\mathrm{B}_{9} \cdot \mathrm{D}_{9 .} \cdot \\
\exp \left(-\mathrm{BC}_{9}\right)\end{array}$ & $\begin{array}{c}\mathrm{B}_{10} \cdot \mathrm{D}_{10} \cdot \\
\exp \left(-\mathrm{BC}_{10}\right)\end{array}$ & $\begin{array}{c}B_{11} \cdot D_{11} \\
\exp \left(-\beta C_{11}\right.\end{array}$ & $\begin{array}{c}\mathrm{B}_{12} \cdot \mathrm{D}_{12} \\
\exp \left(-\mathrm{BC}_{\mathrm{i}_{12}}\right)\end{array}$ & \begin{tabular}{|c|}
$\mathbf{B}_{13} \cdot D_{13} \cdot$ \\
$\exp \left(-\mathrm{BC}_{13}\right.$
\end{tabular} & $\begin{array}{c}\mathbf{B}_{14} \cdot D_{14 \cdot} \\
\exp \left(-\mathrm{BC}_{14}\right)\end{array}$ & $\begin{array}{c}\mathrm{B}_{15}, \mathrm{D}_{15 \cdot} \\
\exp \left(-\mathrm{BC}_{15}\right)\end{array}$ & $\begin{array}{c}\mathrm{B}_{16} \cdot \mathrm{D}_{16} \\
\exp \left(-\mathrm{B}_{16}\right.\end{array}$ & Total & $\mathrm{A}=1 /$ TOTAL $]$ \\
\hline 1 & 0,2901 & 0,0860 & 0,0245 & 0,0139 & 0,1572 & 0,0226 & 0,0186 & 0,0071 & 0,0047 & 0,0058 & \begin{tabular}{|l|}
0,0026 \\
\end{tabular} & $\begin{array}{l}0,0017 \\
\end{array}$ & \begin{tabular}{|c|}
0,0069 \\
\end{tabular} & 0,0101 & 0,0390 & \begin{tabular}{|l|}
0,0083 \\
\end{tabular} & 0,6989 & 1,43091088 \\
\hline 2 & 0,1567 & 0,1592 & 0,1029 & 0,0350 & 0,1042 & 0,0085 & 0,0082 & 0,0045 & 0,0025 & 0,0032 & 0,0014 & 0,0009 & 0,0037 & 0,0096 & 0,0210 & 0,0045 & 0,6260 & 1,59737422 \\
\hline 3 & 0,0223 & 0,0515 & 0,3184 & 0,1141 & 0,3063 & 0,0488 & 0,0638 & 0,0257 & 0,0170 & 0,0211 & 0,0092 & 0,0060 & 0,0134 & 0,0363 & 0,1406 & 0,0162 & 1,2106 & 0,82603086 \\
\hline 4 & 0,0080 & 0,0110 & 0,0719 & 0,5055 & 0,0691 & 0,0110 & 0,0144 & 0,0058 & 0,0038 & 0,0048 & 0,0021 & 0,0014 & 0,0030 & 0,0082 & 0,0317 & 0,0037 & 0,7554 & 1,32385181 \\
\hline 5 & 0,0804 & 0,0293 & 0,1720 & 0,0616 & 0,5671 & 0,0904 & 0,1181 & 0,0476 & 0,0314 & 0,0391 & 0,0170 & 0,0111 & 0,0247 & 0,0494 & 0,1726 & 0,0476 & 1,5595 & 0,64124228 \\
\hline 6 & 0,0481 & 0,0100 & 0,1141 & 0,0409 & 0,3761 & 0,1363 & 0,2078 & 0,0718 & 0,0474 & 0,0589 & 0,0257 & 0,0167 & 0,0373 & 0,0328 & 0,1145 & 0,0316 & 1,3698 & 0,73001945 \\
\hline 7 & 0,0172 & 0,0042 & 0,0649 & 0,0232 & 0,2138 & 0,0904 & 0,3133 & 0,1083 & 0,0714 & 0,0888 & 0,0388 & 0,0253 & 0,0562 & 0,0217 & 0,0651 & 0,0179 & 1,2206 & 0,81929371 \\
\hline 8 & 0,0080 & 0,0028 & 0,0316 & 0,0113 & 0,1042 & 0,0378 & 0,1309 & 0,2592 & 0,0923 & 0,0888 & 0,0388 & 0,0604 & 0,1345 & 0,0423 & 0,1269 & 0,0350 & 1,2048 & 0,83000104 \\
\hline 9 & 0,0062 & 0,0018 & 0,0245 & 0,0088 & 0,0806 & 0,0292 & 0,1013 & 0,1083 & 0,2209 & 0,0287 & 0,0097 & 0,0082 & 0,0182 & 0,0070 & 0,0210 & 0,0058 & 0,6802 & 1,47012914 \\
\hline 10 & 0,0048 & 0,0014 & 0,0189 & 0,0068 & 0,0624 & 0,0226 & 0,0784 & 0,0648 & 0,0179 & 0,3552 & 0,1550 & 0,0574 & 0,0939 & 0,0144 & 0,0190 & 0,0102 & 0,9830 & 1,01726089 \\
\hline 11 & 0,0006 & 0,0002 & 0,0024 & 0,0009 & 0,0080 & 0,0029 & 0,0101 & 0,0083 & 0,0018 & 0,0456 & 1,2076 & 0,0074 & 0,0120 & 0,0018 & 0,0024 & 0,0013 & 1,3134 & 0,76139237 \\
\hline 12 & 0,0014 & 0,0004 & 0,0055 & 0,0020 & 0,0182 & 0,0066 & 0,0229 & 0,0453 & 0,0052 & 0,0589 & 0,0257 & 0,3462 & 0,0939 & 0,0402 & 0,0478 & 0,0408 & 0,7610 & 1,31413577 \\
\hline 13 & 0,0072 & 0,0021 & 0,0154 & 0,0055 & 0,0508 & 0,0184 & 0,0638 & 0,1263 & 0,0145 & 0,1209 & 0,0527 & 0,1178 & 0,2759 & 0,0423 & 0,0530 & 0,0718 & 1,0386 & 0,96280234 \\
\hline 14 & 0,0247 & 0,0129 & 0,0978 & 0,0350 & 0,2370 & 0,0378 & 0,0576 & 0,0928 & 0,0131 & 0,0433 & 0,0189 & 0,1178 & 0,0988 & 0,1182 & 0,1480 & 0,1139 & 1,2676 & 0,78891053 \\
\hline 15 & 0,0457 & 0,0135 & 0,1810 & 0,0649 & 0,3959 & 0,0631 & 0,0825 & 0,1330 & 0,0188 & 0,0273 & 0,0119 & 0,0670 & 0,0592 & 0,0707 & 0,2473 & 0,0682 & 1,5499 & 0,64518893 \\
\hline 16 & 0,0043 & 0,0013 & 0,0092 & 0,0033 & 0,0483 & 0,0077 & 0,0101 & 0,0162 & 0,0023 & 0,0065 & 0,0028 & 0,0253 & 0,0354 & 0,0241 & 0,0301 & 0,5593 & 0,7861 & 1,27203974 \\
\hline
\end{tabular}

Tabel 10. Nilai $A_{i}$ dan $B_{d}$ yang diperoleh pada setiap pengulangan 
RABIT : Jurnal Teknologi dan Sistem Informasi Univrab

Volume 4 No. 2 | Juli 2019 : 97-108

\begin{tabular}{|c|c|c|c|c|c|c|c|c|c|c|c|c|c|c|c|}
\hline engulangan & 1 & 2 & 3 & 4 & 5 & 6 & 7 & 8 & 9 & 10 & 11 & 12 & 13 & 14 & 15 \\
\hline$A_{I}$ & 0000 & 24978707 & 43091088 & 5301722 & ,34238010 &, 34740077 & 35531866 & 1,36235933 & 36748766 & 1,37061605 & 1,37197737 & 1,37188465 & 1,37063934 & 1,36850052 & 1,36850052 \\
\hline$A_{2}$ & 0000000 & 4215 & 9737422 & 4348801 & 3989331 & 4868414 & 55918380 & 66806759 & 77447238 & 57842396 & .58024680 & 1,58033040 & 1,57903930 & 1,57668361 & 1,57668361 \\
\hline$A_{3}$ & 0000000 & 7547394 & 2603086 & 88841207 & 0,90967237 & 92057723 & 92738099 & 0,93167100 & 0,93412817 &, 93518788 & 0,93517524 & 0,93434275 & 0,93288721 & 0,93096110 & 0,93096110 \\
\hline$A_{4}$ & & \begin{tabular}{ll|l}
756587 \\
\end{tabular} & 2385181 & 8043963 & 2688523 & 5653922 & 7522809 & 8710552 & 49447789 & 1,49866593 & & & & & \\
\hline$A_{5}$ & & & & & & & & & & & 71397165 & &, 71186484 & & 0,07027650 \\
\hline$A_{6}$ & 000000 & 5838352 & 73001945 & 76887792 & 0,78230786 & 78890520 & 0,79260361 & 0,79455463 & 0,79527935 & 0,79510080 & 0,79424836 & 0,79289226 & 0,79116041 & 0,78914914 & 0,78914914 \\
\hline$A_{7}$ & 0000 & 45308 & 1929371 & 4250 & 354060 & 559296 & 0,86153477 & 86209157 & 86158367 & 0,86035 & 0,85862440 & 0,85653425 & 0,85418634 & 0,85165252 & 0,85165252 \\
\hline$A_{s}$ & & & & & & & & & & & & & & & \\
\hline$A_{9}$ & 000000 & 8942598 & 47012914 & 48220352 & 1,50461883 & 51807054 & 1,52502694 & 1,52807824 & 1,52865357 & 1,52755691 & 1,52528583 & 1,52217231 & 1,51844817 & 1,51427951 & 1,51427951 \\
\hline$A_{10}$ & 0000000 & 1,10508499 & 01726089 & 98816872 & 0,97431275 & 0,96308792 & 0,95293218 & 0,94385856 & 0,93587073 & 0,92886387 & 0,92268594 & 0,91718125 & 0,91221043 & 0,90765679 & 0,90765679 \\
\hline$A_{11}$ & 000000 & 6439487 & 6139237 & 848102 & 22981784 & 59011177 & 56103071 & 63941925 &, 52313505 & 0,51069588 & 0,50105736 & 0,49347285 & 0,48740257 & 0,48245308 & 0,48245 \\
\hline$A_{12}$ & & & & & & & & & & & & & & & 1,26102347 \\
\hline$A_{13}$ & 0000000 & 02422647 & 0,96280234 & 84602345 & 0,94668490 & 94740273 & 0,94656876 & 0,94461249 & 0,94200021 & 0,93902831 & 0,93586551 & 0,93260473 & 0,92929664 & 0,92596872 & 0,92596872 \\
\hline$A_{14}$ & 0000000 & 8952952 & 8891053 & 1775247 & 22956687 & 83621461 & 84007524 & 84205463 & 84269640 & 0,84237192 & 0,84134368 & 0,83980028 & 0,83787875 & 0,83567954 & 0,83567954 \\
\hline$A_{15}$ & 0000 & & & & & & & & & & 25196 & & 0,70895466 & 30417 & 0,70730417 \\
\hline$A_{16}$ & & & 720 & & & & 395 & & & & & & & 1,34993704 & 1,34993704 \\
\hline$B_{1}$ & \begin{tabular}{|c|}
0000123 \\
\end{tabular} & 00000084 & 00000101 & 0000104 & 0,00000105 & 00000104 &, 00000103 & 00000103 & 0,00000103 & 0,00000102 & 0,00000102 & 0,00000102 & 0,00000102 & 0,00000103 & selesai \\
\hline$B_{2}$ & 0000154 & 0000112 & 0000125 & 00127 & 0000127 & 00000126 & 0,00000126 & 0000125 & 0,00000125 & 0,00000124 & 0,00000124 & 0,00000124 & 0,00000124 & 0,00000125 & elesai \\
\hline$B_{3}$ & 0000103 & 0000134 & . & 0000116 & 00000114 & 00000113 & 00000112 & 00000112 & 0,00000112 & 0112 & 00000112 & 00112 & 0,00000112 & 0,00000112 & \\
\hline$B_{4}$ & 0000236 & 00000223 & 00000218 & 0000209 & 0,00000204 & 00000201 & 00000199 & 00000198 &, 00000197 & 0,00000197 &, 00000196 & 0,00000197 & 0,00000197 &, 00000197 & elesai \\
\hline$B_{5}$ & 20000074 & 0,00000103 & 00000088 & 00000086 & 0,00000084 & 0,00000084 & 0,00000083 & 0,00000083 & 0,00000083 & 0,00000083 & 0,00000083 & 0,00000083 & 0,00000083 & 0,00000084 & selesai \\
\hline$B_{6}$ & \begin{tabular}{l|l}
0000083 \\
\end{tabular} & 0000107 & 0000099 & 0000096 & 0000095 & 00000094 & 0,00000094 & 0000094 & 0,00000094 & 0,00000094 & 0,00000094 & 0,00000094 & 0,00000094 & 0,00000094 & elesai \\
\hline$B_{7}$ & 0000094 & 0000111 & 0000110 & \begin{tabular}{|l|l|l|l|}
000108 \\
\end{tabular} & 0000107 & 00000106 & 00000106 & 00000106 &, 00000106 & & 00000106 & 0,00000106 & 0107 & & \\
\hline$B_{g}$ & 50000106 & 0,00000114 & 00000118 & 00000117 & 0,00000116 & 0,00000115 & 0,00000115 & 00000115 & 0,00000115 & 0,00000115 & 0,00000115 & 0,00000116 & 0,00000116 & 0,00000116 & selesai \\
\hline$B_{9}$ & & 0,00000168 & 00000172 & 0,00000170 & 0,00000167 & 0,00000166 & 0,00000166 & 0,00000166 & 0,00000166 & 0,00000166 & 0,00000166 & 0,00000166 & 0,00000167 & 0,00000167 & selesai \\
\hline & & & & & & & & & & & & & & & \\
\hline$B$ & 20000155 & 0,00000176 & 00000198 & 0000216 & 000002 & 45 & 255 & & & & 280 & 0,00000 & 0,00000287 & 0,00000289 & \\
\hline$B_{12}$ & 00000199 & 0,00000186 & 0,00000194 & 0,00000195 & 0,00000195 & 0,00000195 & 0,00000195 & 0,00000195 & 0,00000195 & 0,00000196 & 0,00000196 & 0,00000197 & 0,00000198 & 0,00000198 & elesai \\
\hline & & 0,00000130 & & & & & & & & & & & & & elesai \\
\hline & 000096 & & & & & & & & & & & & & & \\
\hline$B_{15}$ & 0,00000081 & 0,00000106 & 0,00000096 & 0,00000093 & 0,00000092 & 0,00000091 & 0,00000091 & 0,00000091 & 0,00000091 & 0,00000091 & 0,00000091 & 0,00000091 & 0,00000091 & 0,00000091 & selesai \\
\hline$B_{16}$ & 0,00000271 & 0,00000264 & 0,00000260 & 0,00000255 & 0,00000252 & 0,00000249 & 0,00000248 & 0,00000247 & 0,00000247 & 0,00000247 & 0,00000247 & 0,00000247 & 0,00000248 & 0,00000249 & selesai \\
\hline
\end{tabular}

Pada Tabel 10. memperlihatkan nilai $A_{i}$ dan $B_{d}$ pada setiap pengulangan. Perhitungan berhenti pada pengulangan ke-15 dimana nilai $A_{i}$ untuk setiap $\underline{i}$ dan nilai $B_{d}$ untuk setiap $d$ tidak lagi mengalami perubahan (atau telah mencapai konvergensi). Setelah tercapai konvergensi dengan mendapatkan nilai $A_{i}$ dan $B_{d}$ untuk setiap $\underline{i}$ dan $\underline{d}$ maka setiap sel matriks dapat dihitung dengan menggunakan persamaan (2) sehingga menghasilkan matriks akhir seperti yang terlihat pada Tabel 11.

Tabel 11. MAT akhir hasil model PACGR (Setelah pengulangan ke-15)

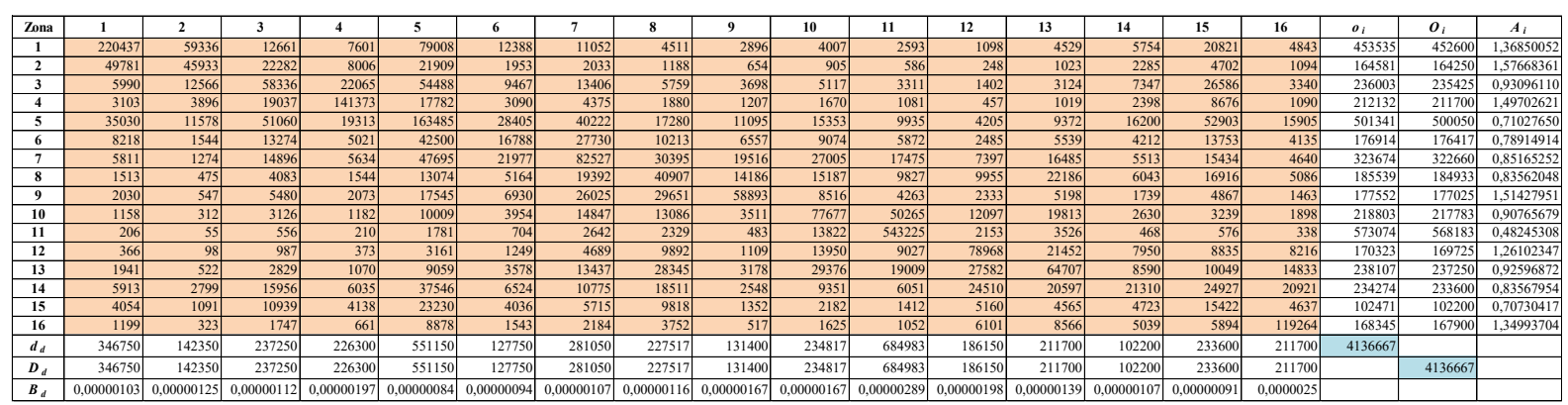

Berdasarkan Tabel 11. terlihat bahwa hasil akhir Matrik Asal Tujuan (MAT) dengan Model PACGR dengan batasan bangkitan tarikan setelah mencapai konvergensi yaitu pada pengulangan ke-15 menunjukkan sebaran pergerakan yang terjadi pada setiap kecamatan di Kabupaten Rokan Hulu. Sebaran pergerakan terbesar yang terjadi di Kabupaten Rokan Hulu sebesar $75 \%$ berbasis pergerakan internal. Hal ini dapat dinyatakan bahwa asal dan tujuan pergerakan yang terjadi berada dalam zona yang sama. Dapat dilihat bahwa sebanyak 12 zona (kecamatan) dari 16 zona (kecamatan) yang ada di kabupaten Rokan Hulu antara lain kecamatan Rokan IV Koto, Tandun, Kabun, Ujung Batu, Rambah, Rambah Hilir, Bangun Purba, Tambusai, Tambusai Utara, Kepenuhan, Kepenuhan
Hulu, dan Bonai Darussalam yang mengalami sebaran pergerakan terbesar yang berbasis pergerakan internal. Salah satu contoh pergerakan yang berasal dari zona 1 atau kecamatan Rokan IV Koto yang mempunyai tujuan pergerakan terbesar di zona yang sama yaitu sebesar $220437 \mathrm{smp} /$ jam pergerakan yang terjadi di zona tersebut.

Namun pada empat zona lainnya yaitu zona 2 (Kecamatan Pendalian IV Koto), zona 6 (Kecamatan Rambah Samo), zona 14 (Kecamatan Kunto Darussalam), dan zona 15 (Kecamatan Pagaran Tapah) sebaran pergerakan terbesar yang terjadi berbasis pergerakan antar zona. Seperti yang dijelaskan pada Gambar 3. untuk Kecamatan Pendalian IV Koto sebaran pergerakan terbesar yang terjadi yaitu 
pergerakan yang mempunyai tujuan ke kecamatan Rokan IV Koto sebesar 49781 smp/jam sedangkan

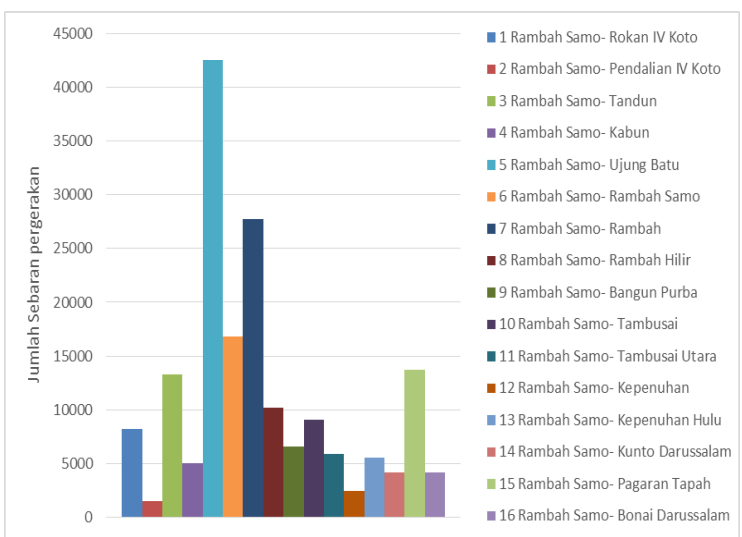

Gambar 3. Sebaran pergerakan Kecamatan Pendalian IV Koto pada setiap kecamatan di Kabupaten Rokan Hulu

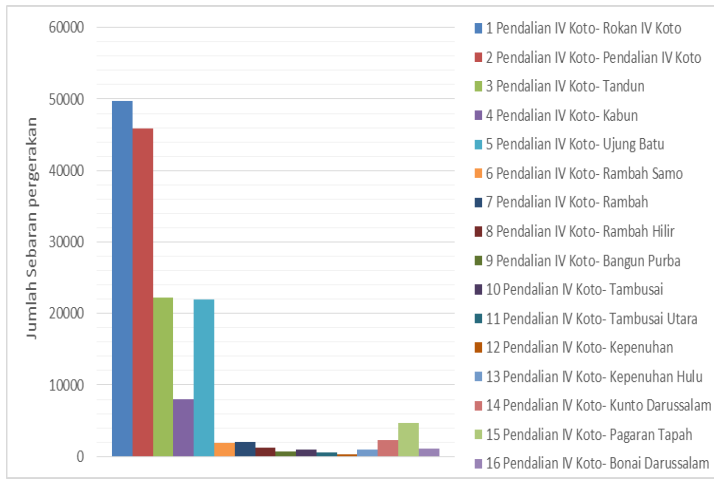

Gambar 4. Sebaran pergerakan Kecamatan Rambah Samo pada setiap kecamatan di Kabupaten Rokan Hulu

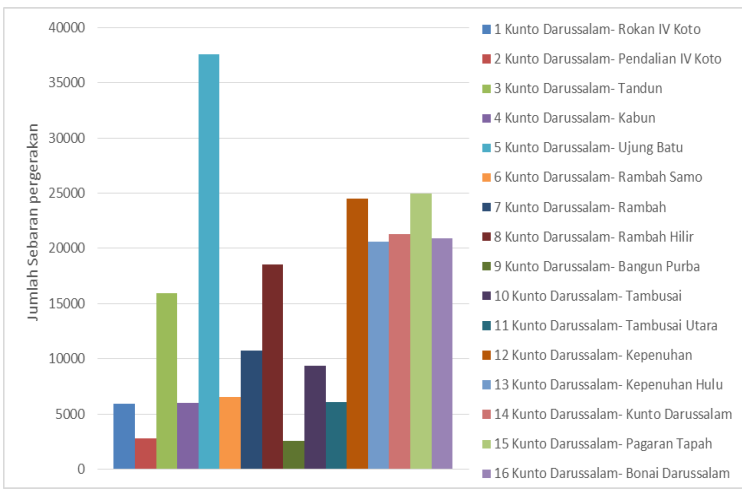

Gambar 5. Sebaran pergerakan Kecamatan sebaran pergerakan yang terkecil pergerakan yang menuju Kecamtan Kepenuhan sebesar 248 smp/jam

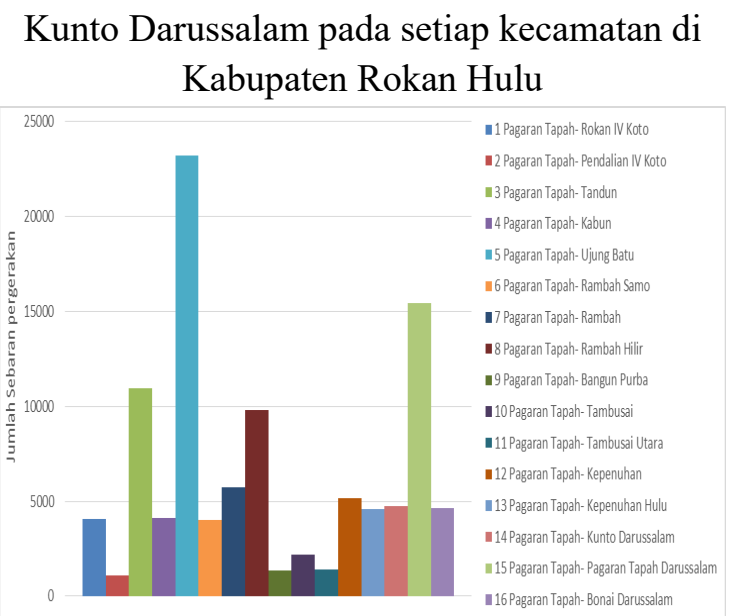

Gambar 6. Sebaran pergerakan Kecamatan

Pagaran Tapah pada setiap kecamatan di Kabupaten Rokan Hulu

Sebaran pergerakan antar zona yang terjadi pada kecamatan Rambah Samo, Kunto Darussalam dan Pagaran Tapah sebaran pergerakan terbesar yang terjadi yaitu yang mempunyai tujuan pergerakan ke kecamatan Ujung Batu. Pergerakan dari Kecamatan Rambah Samo menuju Kecamatan Ujung Batu sebesar 42500 smp/jam, Kecamatan Kunto Darussalam menuju Kecamatan Ujung Batu sebesar 37546 smp/jam dan Kecamatan Pagaran Tapah menuju Kecamatan Ujung Batu sebesar 23230 smp/jam sebagaimana yang dijelaskan pada Gambar 4-6. Hal ini dikarenakan Kecamatan Ujung Batu merupakan pusat industri dan perdagangan di Kabupaten Rokan Hulu. Jika dilihat dari Gambar 7. Sebaran pergerakan antar zona didominasi dengan jarak terpendek. Hal yang sama juga diperoleh sebaran pergerakan barang pokok dan strategis internal regional di Provinsi Jawa Tengah yang mempunyai kecenderungan frekuensi pergerakan didominasi pergerakan antar zona dengan jarak terpendek (Akbardin, Juang., 2013). 


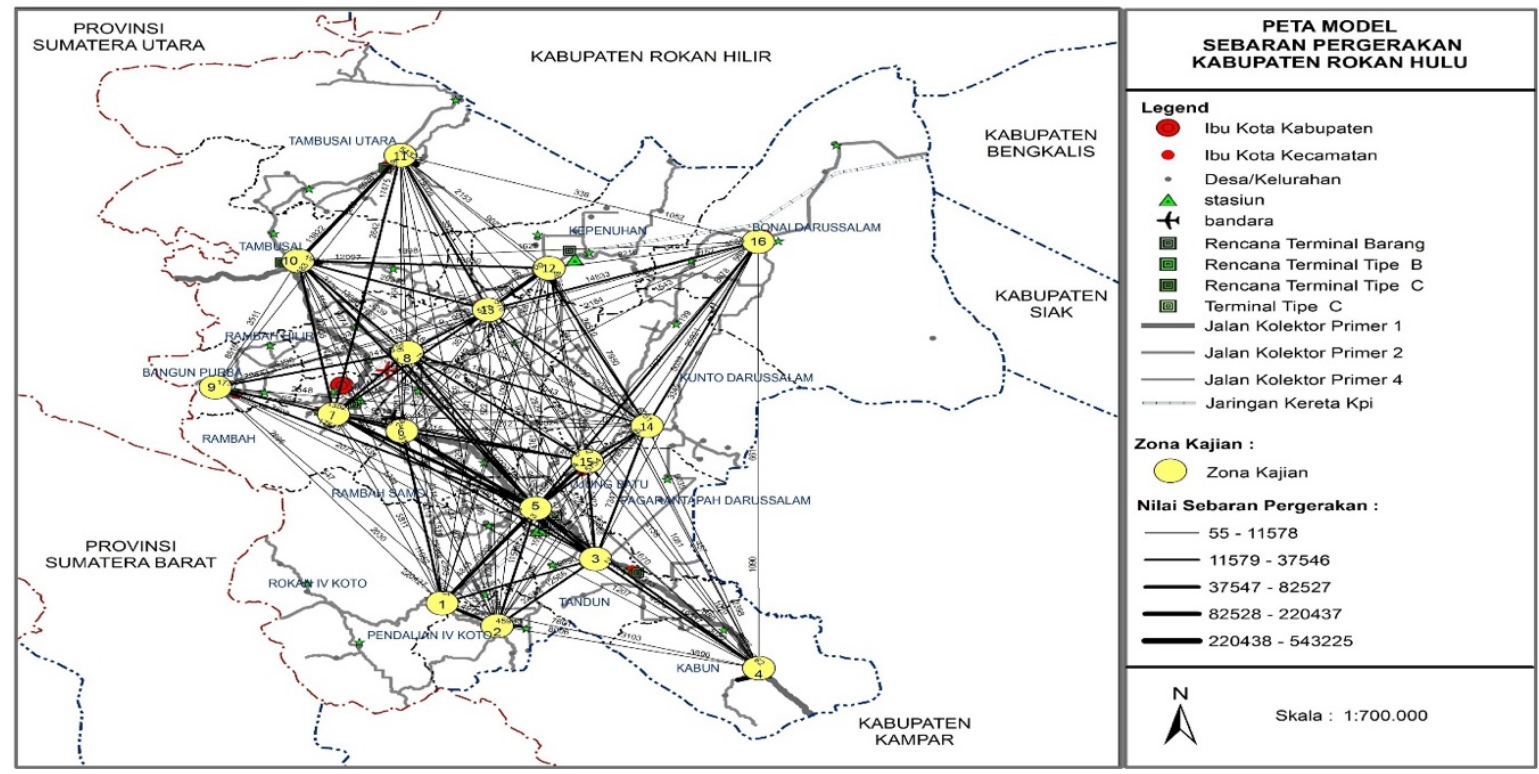

Gambar 7. Peta sebaran pergerakan (desire line) masyarakat Kabupaten Rokan hulu dengan SIG

Sebaran pergerakan di Kabupaten Rokan Hulu dapat juga di ilustrasikan dalam system informasi geografis (SIG) yang berupa garis keinginan pergerakan masyarakat yang mempunyai dimensi spasial atau ruang yang lebih mudah di gambarkan secara grafis. Seperti yang terlukis di Gambar 7 semakin tebal garis keinginan menyatakan jumlah pergerakan yang berasal maupun menuju zona tersebut semakin besar begitu pula sebaliknya, semakin tipis garis keinginan dalam SIG tersebut menyatakan jumlah pergerakan yang berasal dan menuju zona tersebut semakin kecil.

\section{KESIMPULAN}

Dari hasil penelitian diperoleh beberapa kesimpulan sebagai berikut:

1. Sebaran pergerakan terbesar yang terjadi di Kabupaten Rokan Hulu sebesar 75\% berbasis pergerakan internal antara lain kecamatan Rokan IV Koto, Tandun, Kabun, Ujung Batu, Rambah, Rambah Hilir, Bangun Purba, Tambusai, Tambusai Utara, Kepenuhan, Kepenuhan Hulu, dan Bonai Darussalam yang mengalami sebaran pergerakan terbesar yang berbasis pergerakan internal dengan kata lain pergerakan yang terjadi berada dalam zona yang sama.

2. Pergerakan antar zona yang terjadi sebesar $25 \%$ yakni empat zona (kecamatan) yang ada di Kabupaten Rokan Hulu yaitu zona 2 (Kecamatan Pendalian IV Koto), zona 6 (Kecamatan Rambah Samo), zona 14 (Kecamatan Kunto Darussalam), dan zona 15 (Kecamatan Pagaran Tapah) sebaran pergerakan terbesar yang terjadi berbasis pergerakan antar zona. Pada Kecamatan Pendalian IV Koto sebaran pergerakan terbesar yang terjadi yaitu pergerakan yang mempunyai tujuan ke kecamatan Rokan IV Koto. Sedangkan untuk kecamatan Rambah Samo, Kunto Darussalam dan Pagaran Tapah sebaran pergerakan terbesar yang terjadi yaitu yang mempunyai tujuan pergerakan ke kecamatan Ujung Batu. Hal ini dikarenakan Kecamatan Ujung Batu merupakan pusat industri dan perdagangan di Kabupaten Rokan Hulu. 


\section{DAFTAR PUSTAKA}

[1] Akbardin, Juang, 2013, Studi Pemodelan Sebaran Pergerakan Barang Pokok dan Strategis Internal Regional Studi Kasus: Provinsi Jawa Tengah, Jurnal Tekno Sipil, Vol. 11 No.58, Program Studi Teknik Sipil Universitas Pendidikan Indonesia, Bandung.

[2] Aprilliansyah, T., Herman, 2014, Perkiraan Distribusi Pergerakan Penumpang di Provinsi Jawa Barat Berdasarkan Asal Tujuan Transportasi Nasional, Jurnal Online Institut Teknologi Nasional, Vol.1 No.1, Jurusan Teknik Sipil, Fakultas Teknik Sipil dan Perencanaan Institut Teknologi Nasional, Bandung.

[3] Badan Pusat Statistik Kabupaten Rokan Hulu, 2017, "Kabupaten Rokan Hulu Dalam Angka", Katalog BPS, Pasir Pangarayan.

[4] Ekowicaksono, Imam, 2016, Estimasi Matriks Origin-Destination Perkotaan Menggunakan Model Gravity: Studi Kasus Kota Bogor, Tesis Program Studi Matematika Terapan, Institut Pertanian Bogor.

[5] Pramesti, N.D., dkk, 2014, Analisis Distribusi Perjalanan Menggunakan Model Gravitasi Dua Batasan dengan Optimasi Fungsi Hambatan Studi Kasus: Kota Semarang dan Kota Surakarta, Jurnal Karya Teknik Sipil,
Vol. 3, No.1, Halaman 229: Fakultas Teknik, Universitas Diponegoro Semarang.

[6] Ramdhani, F., Tisnawan, R., 2018, Analisis Model Bangkitan dan Tarikan Pergerakan Kabupaten Rokan Hulu, Jurnal Rab Construction Research, Vol. 3, No.1, Program Studi Teknik Sipil, Universitas Abdurrab Pekanbaru.

[7] Suyuti, R dan Tamin, O.Z. 2007. Penggunaan Model Gravity (GR) dalam Estimasi Matriks Asal-Tujuan (MAT) Menggunakan Data Arus Lalu Lintas. Jurnal Transportasi Vol. 7 No. 2 Desember 2007: 115-126 115

[8] Tamin, O.Z., 2008, Perencanaan, Pemodelan dan Rekayasa Transportasi: Teori, Contoh Soal dan Aplikasi, Penerbit ITB, Bandung.

[9] Tamin, O.Z, 2014, Metode Estimasi Matrik Asal Tujuan (MAT) untuk Peramalan Kebutuhan Transportasi: Teori, Contoh Soal dan Aplikasi, Penerbit ITB, Bandung.

[10] Wayongkere, V., Ferdinandus, R.R.J, 2012, Sebaran Pergerakan Kota Manado dengan Menggunakan Metode Sistetis Gravity Dua Batasan, Jurnal Sabua Vol. 4 No. 3: 29-36, Program Studi Perencanaan Wilayah dan Kota (PWK), Jurnal Arsitektur, Fakultas Teknik Universitas Sam Ratulangi Manado. 